\title{
Holocene Break-up and Reestablishment of the Petermann Ice Tongue, Northwest Greenland
}

Brendan T. Reilly ${ }^{1 *}$, Joseph S. Stoner ${ }^{1}$, Alan C. Mix ${ }^{1}$, Maureen H. Walczak ${ }^{1}$, Anne Jennings ${ }^{2}$, Martin Jakobsson ${ }^{3}$, Laurence Dyke ${ }^{4}$, Anna Glueder ${ }^{1}$, Keith Nicholls ${ }^{5}$, Kelly A. Hogan ${ }^{5}$, Larry A. Mayer $^{6}$, Robert G. Hatfield ${ }^{1}$, Sam Albert, ${ }^{1}$ Shaun Marcott, ${ }^{7}$ Stewart Fallon ${ }^{8}$, Maziet Cheseby ${ }^{1}$

${ }^{1}$ College of Earth, Ocean, and Atmospheric Sciences, Oregon State University, Corvallis, Oregon 97331, USA

${ }^{2}$ Institute of Arctic and Alpine Research, University of Colorado, Boulder, CO 80309-0450, USA.

${ }^{3}$ Department of Geological Sciences, Stockholm University, 10691 Stockholm, Sweden.

${ }^{4}$ Geological Survey of Denmark and Greenland, Department of Glaciology and Climate, Øster Voldgade 10, DK-1350, København K, Denmark.

${ }^{5}$ British Antarctic Survey, Natural Environmental Research Council, High Cross, Madingley Road, Cambridge, CB3 OET, UK

${ }^{6}$ Center for Coastal and Ocean Mapping, University of New Hampshire, NH 03824, USA

${ }^{7}$ Department of Geoscience, University of Wisconsin-Madison, Madison, WI, 53706, USA

${ }^{8}$ Radiocarbon Laboratory, Research School of Earth Sciences, The Australia National University, Canberra, ACT, Australia

*Correspondence to: breilly@ ceoas.oregonstate.edu

Keywords: Holocene; Glaciology; Greenland Ice Sheet; Sedimentology-marine sediment cores; Petermann Glacier; Petermann Ice Tongue; Ice Shelf; Paleomagnetism; Paleomagnetic Secular Variation 
42

43

44

45

46

47

48

49

50

51

52

53

54

55

- A transect of sediment cores constrain past retreat and advance of Petermann Glacier's floating ice tongue in response to climate change.

- Particle-size specific properties disentangle sedimentary source and transport signals

- Multi-proxy age-depth modeling constrains the timing of glacial changes

- Petermann Ice Tongue broke-up during early Holocene warming and was absent for nearly five of the last seven thousand years

- Historically observed ice tongue extents of Petermann Glacier are only characteristic of the latest Holocene 


\section{Abstract}

Over the last decade, two major calving events of the Petermann Ice Tongue in Northwest Greenland have led to speculation on its future stability and contribution to further Greenland Ice Sheet mass loss. However, it has been unclear if these events are anomalous or typical within the context of limited historical observations. We extend the historical record of the floating ice tongue using the stratigraphy of Petermann Fjord sediments to provide a longerterm perspective. Computed tomography (CT) scans, X-Ray Fluorescence (XRF) scans, IceRafted Debris (IRD) counts, and the magnetic properties of specific particle size fractions constrain changes in depositional processes and sediment sources at our core sites, allowing for reconstructions of past behavior of the Petermann Ice Tongue. Radiocarbon dating of foraminifera, ${ }^{210} \mathrm{~Pb}$, and paleomagnetic secular variation (PSV) provide age control and help to address uncertainties in radiocarbon reservoir ages. A floating ice tongue in Petermann Fjord formed in late glacial time as Petermann Glacier retreated from an advanced grounded position. This paleo-ice tongue broke-up during the early Holocene when high northern latitude summer insolation was higher than present. After gradual regrowth of the ice tongue associated with regional cooling, the ice tongue reached its historical extent only within the last millennium. Little or no ice tongue was present for nearly 5000 years during the middle Holocene, when decadal mean regional temperatures are estimated to be $0.8-2.9{ }^{\circ} \mathrm{C}$ higher than preindustrial (1750 CE) and seasonal sea-ice in the Lincoln Sea was reduced. This pre-historical behavior shows that recent anthropogenic warming may already be in the range of ice tongue instability and future projected warming increases the risk of ice tongue break-up by the mid- $21^{\text {st }}$ Century. 


\section{Introduction}

The Greenland Ice Sheet (GIS) is losing mass at an accelerated rate (Rignot et al., 2011; Velicogna et al., 2014) and holds the potential for $\sim 7.4 \mathrm{~m}$ of sea level rise above modern levels (Morlighem et al., 2017). While the $21^{\text {st }}$ century sea level projections of the Intergovernmental Panel on Climate Change Assessment Report 5 (IPCC AR5) now include dynamic responses from ice sheets, these dynamic responses are still a large source of uncertainty (Stocker et al., 2013). Beyond these dynamic changes, the impact of sea-level rise on humanity will extend much further than 2100 as ice sheets will continue to respond to the present anthropogenic climate perturbation for centuries to millennia (Clark et al., 2016). The geologic record provides a means to observe interactions between the cryosphere and climate system on centennial, millennial, and orbital timescales, capturing past examples of both dynamic and longer-term ice sheet responses to Earth system changes.

Petermann Glacier, which drains much of the northwest GIS (Rignot and Kanagaratnam, 2006), terminates as a floating ice tongue. Basal melting accounts for $80 \%$ of Petermann Ice Tongue's negative mass balance, making it particularly sensitive to ice-ocean interactions (Rignot and Steffen, 2008; Münchow et al., 2014; Cai et al., 2017). Unlike Greenland's other large marine terminating outlet glaciers, particularly Zachariæ Isstrøm (Mouginot et al., 2015) and Jakobshavn Isbræ (Joughin et al., 2014), Petermann Glacier has been relatively stable over most of its observed history (Rignot and Kanagaratnam, 2006; Nick et al., 2012; Hogg et al., 2016). However, large calving events in 2010 and 2012 have reduced the ice tongue length from a historical range of $\sim 70-90 \mathrm{~km}$ beyond its grounding zone to $\sim 45-50 \mathrm{~km}$, which is shorter than any historical observations since its initial mapping by the 1875-1876 British Arctic Expedition of Sir Nares (Falkner et al., 2011; Münchow et al., 2014; Nares, 1878). This calving may 
101

102

103

represent a departure from steady state mass balance, however given limited historical data it is uncertain whether these events were anomalous, or within past norms (Falkner et al., 2011; Münchow et al., 2014, 2016; Washam et al., 2018).

The fate of the Petermann Ice Tongue is plausibly linked to its interactions with the warm modified Atlantic Water (AW) that fills the fjord at depths below 400 m (Heuzé et al., 2016; Johnson et al., 2011). This warmer water enters the fjord across a sill with maximum depth of 443 m (Jakobsson et al., 2018), having first circulated through the Arctic Ocean and Nares Strait (Heuzé et al., 2016). While some observations suggest inflowing AW is warming (Münchow et al., 2011), recent observation and modeling also highlight mechanisms that could strengthen the fjord circulation and thereby increase the flux of warmer water interacting with the Petermann Ice Tongue. For example, a decrease in extent or increase in mobility of sea ice in Nares Strait would increase Ekman transport of AW into the fjord (Shroyer et al., 2017) and increased subglacial run-off driven by surface-air warming and surface melting would increase entrainment of warm AW in buoyant plumes seaward of Peterman Glacier's grounding zone (Cai et al., 2017; Washam et al., in review).

Seafloor morphology suggests an early Holocene regional deglaciation with retreat of the Petermann Glacier from a past grounding zone on a prominent shallow sill bordering Hall Basin via marine ice cliff instability around 7.5 ka (Jakobsson et al., 2018). The Petermann 2015 Expedition recovered the first suite of sediment cores ever taken from the fjord, outboard of the historical ice front, in the zone of open water exposed by recent calving, and (by drilling through the ice) from under the existing ice tongue. These cores document a long history of the fjord's glaciers and floating ice tongue since the early Holocene retreat and provide a centennialmillennial timescale context for the historical record (Figures 1-2; Supplementary Table S1). 
124 These sediment archives span a period of time in the middle Holocene when oceanographic conditions in Nares Strait were different (Jennings et al., 2011), regional surface air temperatures were higher (Axford et al., 2019; Buizert et al., 2018; Lasher et al., 2017; Lecavalier et al., 2017; McFarlin et al., 2018), seasonal sea-ice cover in the Lincoln Sea was reduced (England et al., 2008; Funder et al., 2011), and the northwest sector of the GIS was likely smaller (Farnsworth et al., 2018; Lecavalier et al., 2017; Reusche et al., 2018) relative to late Holocene/preindustrial times. Model comparisons suggest the middle Holocene may be a suitable analog for future warming in the High Arctic despite differences in the underlying forcing (i.e., insolation versus greenhouse gasses, respectively) (Yoshimori and Suzuki, 2018).

\section{Materials and Methods}

\subsection{Sediment Cores}

Sediment cores were collected from Petermann Fjord during the international Petermann 2015 Expedition onboard the Swedish Icebreaker Oden (OD1507) (Figures 1-2; Supplementary Table S1). Petermann Fjord multicores (MC), gravity cores (GC), piston cores (PC), and trigger cores (TC) were recovered from Oden seaward of the 2015 ice tongue extent. Additional sediment cores were collected from beneath the ice tongue at locations about 15 and $25 \mathrm{~km}$ seaward of the 2015 grounding zone using a modified UWITEC corer (UW) through holes drilled using the British Antarctic Survey ice-shelf hot water drill (Makinson and Anker, 2014; Münchow et al., 2016). 
Following recovery, whole round sediment cores were measured at $1 \mathrm{~cm}$ intervals for magnetic susceptibility, gamma ray attenuation, resistivity, and p-wave velocity using the piston cores recovered from Petermann Fjord were split, photographed using a GEOTEK Line Scan Camera, and described onboard. Multicores, trigger cores, and the sub-ice tongue UWITEC cores were split, photographed, and described in May 2016 at the OSU Marine and Geology Repository. Toshiba Aquilion 64 Slice Medical CT Scanner at the OSU College of Veterinary Medicine at

$154120 \mathrm{kV}$, converted into $2 \mathrm{~mm}$ thick coronal slices with an effective in-plane resolution of about

$1550.5 \times 0.5 \mathrm{~mm}$, and processed using SedCT MATLAB tools (Reilly et al., 2017). X-ray

156 Fluorescence (XRF) scans were made using the OSU Marine and Geology Repository ITRAX

157 XRF Core Scanner, using a Mo Tube and 5 s exposure time. The resolution of XRF scans varied

158 for cores depending on visual and CT scan observations, ranging from $0.5 \mathrm{~mm}$ to $2 \mathrm{~mm}$.

159 Anomalous XRF counts based on extreme values in the counts per second (cps) distributions for 160 each core, typically those with less than $130000 \mathrm{cps}$ or exceeding $200000 \mathrm{cps}$, were cleaned from 161 the dataset, as these data were likely impacted by cracks, section edges, uneven surfaces, or large 162 clasts.

Coring disturbance was not always clearly visible while describing the cores. CT scans

164 were useful for identifying disturbed intervals either through inspection of the sediment fabric or 165 through comparison with nearby cores (examples in Figure 2; Supplementary Figures S1-S3).

166 As different coring methods are better at recovering undisturbed sediments at different depths

167 (e.g., Skinner and McCave, 2003), a spliced record that included the best recovered sections, 
based on CT-scan observations, was made for the outermost fjord cores, 03TC, 41GC, and 03PC. Correlations were based upon XRF Ti/Ca ratios, CT slice images, and CT numbers (CT\#) extracted using SedCT (Supplementary Figure S1; Supplementary Table S2). This spliced record was used as the reference depth scale for creation of a correlated equivalent depth (ced) scale at locations from slight bathymetric highs which are mostly free of gravity deposits forming a transect through the fjord by graphical correlations of XRF Ti/Ca ratios (when available), CT\#s (when available), and magnetic susceptibility (Supplementary Table S3).

\subsection{CT >2 mm Clast Index}

Coarse clastic material in sediment cores that were CT scanned was quantified through an automated image analysis MATLAB routine applied to all $2 \mathrm{~mm}$ thick coronal slices generated for each core. This creates an index of changes in ice rafted debris (IRD) concentration. Similar approaches have been implemented in recent studies using segmentation routines in medical CT software (Bartels et al., 2017), and thresholding of axial slice data in a commercial image analysis program (Hodell et al., 2017). IRD quantification through this method can be easily applied to a large suite of sediment cores and is more objective and reproducible than supervised X-ray IRD counts.

$$
\text { CT\#s, quantified in Hounsfield Units (HU), are calculated as the x-ray attenuation }
$$
coefficient of the sample relative to the attenuation coefficient of water (Hounsfield, 1973), which, in sediment cores, is largely a function of sediment density ( $\rho$ ) (Fortin et al., 2013; Reilly et al., 2017). For clayey sediments recovered from Nares Strait during The Petermann 2015 Expedition, this relationship can be approximated by $\rho=0.8(\mathrm{CT} \#)+1000$ (Reilly et al., 2017). Lithic clasts, like IRD, typically have a higher $\rho$ than the finer-grained sediment matrix they are 
found in, thus allowing these clasts to be identified by setting a representative $\mathrm{CT}$ number threshold. For this study, we choose a CT\# of $2000 \mathrm{HU}\left(\sim 2600 \mathrm{~kg} / \mathrm{m}^{3}\right)$, based on the bimodal distribution of Petermann Fjord CT\# histogram plots. CT slices were used to create a threedimensional matrix with binary values of 0 and 1 assigned to values less than and greater than $2000 \mathrm{HU}$, respectively. Pixels with connected values of 1 were indexed and object volumes were calculated by multiplying the in-plane pixel resolution of the coronal slice, by the $2 \mathrm{~mm}$ slice thickness, by the number of connected pixels. Objects with volumes greater than $4 / 3 \pi \mathrm{mm}^{3}$ (volume of a $2 \mathrm{~mm}$ diameter sphere) where indexed by their central depth and binned in $2 \mathrm{~cm}$ thick depth bins. Bin counts were then normalized by the volume of sediment in each bin, which varies based on the diameter of the core type and if the CT scan was made on a half core or whole round. This is a $>2 \mathrm{~mm}$ clast index, rather than a count of grains, because intervals with tightly packed clasts were likely undercounted if not enough matrix sediment was present between clasts. Similarly, some small clasts were likely undercounted because each pixel in the CT slice is an integration of the objects that fill that space (e.g., a pixel filled 50\% with matrix sediment and 50\% lithic clast may fall below our threshold value). Coarse and well-sorted sand layers that are likely gravity deposits were sometimes greater than our $2000 \mathrm{HU}$ threshold, but had a minimal influence on our results, as these sand layers are well connected and only counted once.

\subsection{Sediment Magnetism}

A subset of cores identified to be representative of the fjord stratigraphy (i.e., free of gravity deposits and with minimal coring deformation) were subsampled using plastic u-channel samples, $2 \mathrm{~cm}$ by $2 \mathrm{~cm}$ by up to $150 \mathrm{~cm} \mathrm{u}$-shaped plastic tubes with clip on lids (e.g., Weeks et 
214 al., 1993). Magnetic measurements on the u-channel samples were made at the OSU Paleo- and

215 Environmental Magnetism Laboratory. Although measurements were made every $1 \mathrm{~cm}$, the

216 effective resolution is an integration of the remanent magnetizations within the response function

217 of the magnetometer ( $\sim 7 \mathrm{~cm}$ width of half height in a Gaussian window). A detailed description

218 of the OSU system is given by Oda and Xuan (2014).

Volume-normalized magnetic susceptibility $(\kappa)$ was measured every $1 \mathrm{~cm}$ using a custom designed automated tracking system and $36 \mathrm{~mm}$ internal diameter Bartington loop sensor with MS3 meter. The natural remanent magnetization (NRM) was measured every $1 \mathrm{~cm}$ before and after alternating field (AF) demagnetization every $5 \mathrm{mT}$ from 10 to $70 \mathrm{mT}$ and every $10 \mathrm{mT}$ from 80 to $100 \mathrm{mT}$ on a $2 \mathrm{G}$ Enterprises ${ }^{\mathrm{TM}}$ model $755-1.65 \mathrm{UC}$ superconducting rock magnetometer with inline AF coils optimized for u-channel samples. An anhysteretic remanent magnetization (ARM) was applied using a $100 \mathrm{mT}$ peak AF field and $0.05 \mathrm{mT}$ biasing field and demagnetized using the same protocol as the NRM. $\kappa_{\mathrm{ARM}}$ was calculated by normalizing the ARM by the biasing field. $\kappa_{\mathrm{ARM}} / \kappa$, a parameter sensitive to changes in magnetic mineral grain-size and mineralogy (Banerjee et al., 1981; King et al., 1982), was calculated by normalizing the $\kappa_{\text {ARM }}$ by

$\kappa$. Flux jumps were monitored for and corrected using UPMAG MATLAB tools (Xuan and Channell, 2009) and the characteristic remanent magnetizations (ChRMs) were isolated using the

231 standard principle component analysis method without anchoring to the origin (Kirschvink, 232 1980) over the 20-60 mT AF demagnetization range (9 steps). assessment of CT scans as recovering the best continuous sections with minimal coring 
and calculating the Fisher mean of the directions within the bin (Fisher, 1953). Uncertainty is quantified as the circular standard error by dividing the circular standard deviation by the square root of the number of the cores that contribute to each bin. We used the number of cores rather than the number of measurements, as neighboring u-channel measurements are not independent due to magnetometer's response function. Stacking the data demonstrates the reproducibility of paleomagnetic directions in the three cores and allows quantification of uncertainty that may be related to coring deformation, geologic processes, or issues in the correlated equivalent depth 244 scale.

To better understand the relationship between sediment magnetic properties and physical particle size, discrete intervals $\left(\sim 10 \mathrm{~cm}^{3}\right)$ from sediment cores 03TC, 03PC, 41GC, 04GC, and 05UW were sampled and separated into nine particle size fractions (see Hatfield, 2014 for review of particle size specific magnetic methodology). Samples were freeze-dried, weighed, dissociated with a dilute Calgon solution, and sonicated for at least 5 minutes, before wet sieving to isolate the $>250 \mu \mathrm{m}, 150-250 \mu \mathrm{m}, 63-150 \mu \mathrm{m}, 45-63 \mu \mathrm{m}, 32-45 \mu \mathrm{m}$, and 20-32 $\mu \mathrm{m}$ fractions. The $10-20 \mu \mathrm{m}, 4-10 \mu \mathrm{m}$, and $<4 \mu \mathrm{m}$ fractions were then isolated by settling the sediment in a graduated cylinder three times according to Stoke's Law, assuming grain densities of 2650 $\mathrm{kg} / \mathrm{m}^{3}$. Particle size fractions were dried in a $45^{\circ} \mathrm{C}$ oven.

For sediment cores 03TC, 03PC, 41GC, and 04GC, mass normalized magnetic susceptibility $(\chi)$ of bulk sediment and the nine sediment size fractions were measured at the

256 Western Washington University (WWU) Pacific Northwest Paleomagnetic Laboratory on an 257 AGICO KLY3-S Magnetic Susceptibility Bridge. Additional rock magnetic measurements on 258 bulk and particle size specific samples from Core 05UW were made at the Montclair State University (MSU) Environmental and Paleomagnetism Laboratory on an AGICO KLY-4 
Susceptibility Bridge and a Princeton Measurements Corporation MicroMag Model 3900

Vibrating Sample Magnetometer (VSM), including hysteresis loops, Direct Current (DC)

We adapt the method of Heslop \& Dillon (2007), which is based on non-negative matrix factorization, to model the particle size distribution of $\chi$ as the linear combination of end-member contributions. In this case, the end-members reflect source contributions, traced by $\chi$, to specific particle size fractions. This approach is justified by laboratory experiments which demonstrate that $\chi$ of a mixture is equal to the linear sum of its components (Hatfield et al., 2017; Lees, 1997). The result of this end-member modeling approach can be influenced by the choice of initial conditions. We quantify this uncertainty using the output of 1000 iterations initialized using random numbers and normalize the $\chi$ contribution to the particle size fraction to the sum $\chi$ for all particle size fractions used.

\subsection{Terrestrial Sediments}

To better understand potential source material to the fjord, terrestrial sediment samples

280 were taken when possible by the 2015 Petermann expedition teams working via helicopter. An 281 attempt was made to find samples with a wide range of grain-sizes representative of material 282 eroded from local catchments (after Hatfield et al., 2017) or from glacial deposits. The samples 
283

284

were split into $<4 \mu \mathrm{m}, 4-63 \mu \mathrm{m}, 63-250 \mu \mathrm{m}$, and $>250 \mu \mathrm{m}$ fractions and a representative subset of the samples was further split into the nine size fractions described for the sediment cores. The $\chi$ of the sediments were measured at WWU as described above. A summary of the terrestrial sediment samples can be found in Supplementary Table S4 and the samples subject to detailed analysis are plotted in Figure 1.

\section{$2.5^{210} \mathrm{~Pb}$, Radiocarbon Dating, PSV, and Age-Depth Estimation}

For $\gamma$-ray spectroscopy, an aliquot of bulk sediment was freeze dried, gently

disaggregated via mortar and pestle (with care taken not to pulverize mineral grains) and weighed prior to analysis in a Canberra GL2020RS LEGe planar $\gamma$-ray detector. Total ${ }^{210} \mathrm{~Pb}$ and

${ }^{214} \mathrm{~Pb}$ activity were simultaneously quantified for each sample, allowing for estimation of excess ${ }^{210} \mathrm{~Pb}$ and accumulation rates via the methods of Wheatcroft et al. (2013).

Foraminifera were picked for radiocarbon dating from $41 \mathrm{GC}, 03 \mathrm{UW}$, and $38 \mathrm{MC}$ and measured at the Australian National University (ANU) Radiocarbon Laboratory (Fallon et al., 2010) (Table 1). Radiocarbon ages were calibrated using the MARINE13 curve (Reimer et al., 2013) and MatCal MATLAB tools (Lougheed and Obrochta, 2016).

As ${ }^{14} \mathrm{C}$ reservoir ages in Petermann Fjord are unknown, we calculate hypothetical agedepth models at $\Delta \mathrm{R}$ values (the difference between the regional radiocarbon age offset and the calibration curve; Stuiver et al., 1986) every 10 years from 0 to 1500 years. At each $\Delta \mathrm{R}$ choice, an ensemble of 1000 age depths models were generated, assuming an upper most sediment age of -65 cal years BP. Our age-depth modeling approach (after Reilly et al., 2018) is inspired by BCHRON (Haslett and Parnell, 2008), but simplified for computation efficiency and integration 
to our MATLAB workflow to allow for efficient calculation of 150,000 model runs per sensitivity test. In addition to age control points randomly selected from calibrated probability distributions at radiocarbon dated horizons, random age-depth control points were added, with a density of about 4 real or simulated age-depth control points per meter (actual numbers vary in each model run). We did not accept any iteration that violates the law of superposition.

To optimize the $\Delta \mathrm{R}$ choice, we compared the Petermann Fjord PSV stack to a well-dated reference template created from reproduced Arctic PSV records- the Western Hemisphere Arctic PSV (WHAP18) Template. We first define regional PSV signals from high-resolution and well-dated sediment cores at $\sim 70^{\circ} \mathrm{N}$ in the Northern North Atlantic, using cores MD99 2269 and 2322 (Dunhill et al., 2004; Kristjánsdóttir et al., 2007; Stoner et al., 2013, 2007), and the

Chukchi Sea, using cores HLY0205 JPC15 and JPC16 (Darby et al., 2012; Keigwin et al., 2006; Lund et al., 2016), and project the directions to Petermann Fjord $\left(81.194{ }^{\circ} \mathrm{N}, 61.977^{\circ} \mathrm{W}\right)$ via their virtual geomagnetic pole (VGP) paths (c.f. Korte et al., 2018; Ólafsdóttir et al., 2019). The goal of the stacking procedure is to average out local or non-geomagnetic signals and capture broad scale geomagnetic field behavior for the Western Hemisphere Arctic. This approach is justified because high-amplitude multi-centennial to millennial wavelength features are broadly consistent on hemispheric length scales when comparing well dated sedimentary records (Stoner et al., 2013; Walczak et al., 2017) and can be predicted by a simple dipole model based on few high quality records with roughly the same precision as more complex spherical harmonic models (Nilsson et al., 2010). The sedimentation rates at the sites used to construct the stack are typically around or in excess of $100 \mathrm{~cm} / \mathrm{ka}$, minimizing the impact of potential depth offsets due to sediment magnetization acquisition processes (lock-in depth; e.g., Stoner et al., 2013; Suganuma et al., 2010), although systematic errors on the order of a few hundred years are 
possible. To ensure each region is weighted equally, preliminary stacks for each region's projected inclination and declination were created using a running 100 year bin size and calculating the Fisher mean and circular standard deviation for directions in that bin (Fisher, 1953). We then generate 1000 possible inclination and declination pairs for each region for each age bin using the associated probability distribution function and calculate the WHAP18 Fisher mean and circular standard error. The circular standard error is calculated from the circular standard deviation by normalizing by the square root of the number of cores used $(\mathrm{N})$, where $\mathrm{N}$ varies from 1-4 depending on the number of cores that span the age bin time interval.

After applying each of the 1000 age-depth models at each $\Delta \mathrm{R}$ value to the Petermann PSV stack, we interpolate to 5 year intervals and calculate the cosine distance $(1-\cos (\theta)$, where $\theta$ is equal to the angle between the two vectors) of the Petermann PSV Stack and WHAP18 stack directions at each time step where the two records overlap. Goodness of fit is quantified by the mean and variance of the cosine distances. In the absence of other information, for the final age model the optimized $\Delta \mathrm{R}$ value is held constant, although we explore the sensitivity of this solution to various assumptions.

\section{Results}

\subsection{Fjord Stratigraphy}

The suite of cores captures a range of depositional regimes that are influenced by proximity to glaciers, water depth, and bathymetry. Comparison of these cores provides the ability to assess coring deformation and local processes that may not be representative of fjord- 
wide signals. The reproducible signals in multiple cores are ultimately the signals we choose to interpret in our discussion of the middle to late Holocene history of the Petermann Ice Tongue.

Well-sorted coarse deposits, either sands or silts, are found in sediment cores taken from deeper bathymetric basins in cores 37PC/TC, 08GC, 10PC, 05UW, 06UW, and 07UW. Just seaward of the 2015 ice tongue extent, we observe these well-sorted coarse deposits in 37PC/TC, raised from $1041 \mathrm{~m}$ depth in a basin near the marine terminating Belgrave Glacier (Figure 1; Supplementary Figure S2). Similar coarse deposits are found at a few horizons in 08GC (1062 $\mathrm{m})$ and 10PC (970 m), although their overall stratigraphy is more consistent to what is observed elsewhere in the fjord. Although there is no marine terminating glacier proximal to these sites, mass wasted blocks are identified nearby in multibeam bathymetry and during the expedition we observed a mass wasting event of the fjord wall just south of the hanging glacier close to these coring locations (Jakobsson et al., 2018).

Well-sorted coarse deposits also dominate the sediments recovered in the sub-ice tongue cores taken about $15 \mathrm{~km}$ from the Petermann grounding-line and near the marine terminating Porsild Glacier, 05UW, 06UW, and 07UW (837 m) (Supplementary Figures S2-S3). While bathymetry has not been observed with acoustic methods beneath the Petermann Ice Tongue, geophysical data suggest these cores were taken from a deeper basin between the Petermann grounding line and a basement sill about $25 \mathrm{~km}$ from the grounding line (Tinto et al., 2015). In all cases, these deposits seem to reflect local depositional processes related to the nearby marine terminating glaciers or mass wasting from the fjord walls.

The cores that best replicate consistent, or fjord-wide, signals were those taken from relative bathymetric highs (Figures 1-2). Sediment is most likely transported to these core locations via suspension settling from fine sediment in the water column and/or as ice rafted 
debris and include: 3PC/TC and 41GC in the outer fjord; 4GC, 6PC/TC, and 40PC/TC just seaward of 2015 ice tongue extent; and cores 02UW and 03UW recovered from beneath the existing ice tongue on the inferred basement sill about $25 \mathrm{~km}$ from the Petermann grounding zone. For the focus of this study, we also include cores 08GC and 10PC/TC, discussed earlier. Except for the few well-sorted coarse layers described in these cores, they also capture the same signal observed at the other locations. Cores taken from shallow water in the southwest fjord, notably 11GC (473 m), also appear to capture the fjord-wide signal, but seem to have much lower sedimentation rates and, as a result, are not studied in detail here.

The Petermann Fjord stratigraphy can be divided into three lithologic units, with the uppermost unit subdivided into three subunits, based on visual inspection of the split core surfaces and CT scans and variations in XRF geochemistry, IRD, and physical properties (Figure 2).

\subsubsection{Lithologic Unit 3}

Unit 3 was recovered at the base of piston cores $03 \mathrm{PC}, 10 \mathrm{PC}, 40 \mathrm{PC}$, and $06 \mathrm{PC}$ and is a sandy mud with abundant coarse particles. Interbedded finer-grained laminated sediments are found at sites that recovered the thickest examples of this unit (06PC and 10PC). While XRF Ti/Ca ratios can reach 0.4 or higher at the cores closer to the 2015 ice tongue edge (06PC and 40PC), Ti/Ca ratios for this unit in the outer fjord are around 0.05 (Figure 2). 


\subsubsection{Lithologic Unit 2}

Unit 2 is clayey mud with absent or low concentrations of dispersed clasts and in some cases faint laminations, most easily visible in the CT scan images. Ti/Ca ratios are lower in Unit 2 than in overlying or underlying sediments. The thickness of this unit is about one meter at the outer fjord sites (03PC and 10PC) and <1 meter at sites closer to the 2015 ice tongue edge (40PC and 06PC).

\subsubsection{Lithologic Unit 1}

Unit 1 is bioturbated clayey mud with dispersed sand and clasts. The degree of bioturbation increases with distance from the grounding line, particularly in the upper part of the unit, with sharper contacts and preservation of faint laminae closer to the grounding zone and low-density burrow features further from the grounding zone (Figure 3d-e; Supplementary Figure S3). These near-surface sediments also show gradients in IRD concentration and sediment geochemistry (Figure $3 \mathrm{~b}$-c). We divide Unit 1 into three subunits, A-C, based on the concentration of coarse material and Ti/Ca ratios. Subunit $1 \mathrm{~A}$ has relatively low Ti/Ca ratios and very low abundances of IRD, Subunit 1B has high Ti/Ca ratios and intermediate abundances of IRD, and Subunit $1 \mathrm{C}$ has a trend from high Ti/Ca and IRD near its base to low Ti/Ca and intermediate IRD concentration near its top. Unit 1 is approximately 4 meters thick at sites that form the main transect in the cores identified as having minimal deformation in their upper sediments by CT scans, including 41GC, 08GC, 40PC/TC, 04GC. 


\subsection{Identifying Variations in and Signatures for Sediment Sources}

The steep fjord walls and bedrock surrounding Petermann Fjord are composed of exclusively Paleozoic Franklinian Basin sedimentary rocks, containing abundant carbonate lithologies (Dawes et al., 2000a). In contrast to this bedrock, terrestrial glacial deposits (e.g., Reusche et al., 2018) and drop stones in the marine sediment cores often contained crystalline rocks, including a very distinctive and abundant pink granitic lithology similar to that of the Precambrian shield exposed in Inglefield Land to the southwest and Victoria Fjord to the northeast (Supplementary Figure S4). Previous work has documented banded iron formation rocks, porphyritic volcanic rocks, dolerite, and the Precambrian shield granites, gneisses and ultramafic rocks in Hall Land and Washington Land glacial deposits, indicating a diverse group of lithologies inland under the ice sheet that are absent from the exposed bedrock beyond the ice sheet margin (Dawes et al., 2000b).

XRF Ti and Ca counts measured on the marine sediment cores from the Fjord show a strong anticorrelation. To illustrate this variation and investigate how variations in sediment geochemical and magnetic properties relate to each other, we perform an R-mode factor analysis on XRF elements with high counts ( $\mathrm{K}, \mathrm{Ca}, \mathrm{Ti}, \mathrm{Mn}, \mathrm{Fe}, \mathrm{Rb}, \mathrm{Sr}, \mathrm{Zr})$ and u-channel magnetic measurements of $\kappa, \kappa_{\mathrm{ARM}}$, and $\kappa_{\mathrm{ARM}} / \kappa$. XRF data and magnetic data were filtered and resampled every $5 \mathrm{~cm}$ using a $\sim 6 \mathrm{~cm}$ wide (at half-height) Gaussian filter to align the chemical data with the response function of the magnetometer (after Walczak et al., 2015). We use measurements from 03PC/TC, 04GC, 10PC, 41GC, 40TC, and 40PC, as those cores had both XRF and u-channel magnetic data.

After centering the data to a mean of zero and normalizing by the standard deviation for each parameter, over $90 \%$ of the variance is explained by the first three factors, which we keep 
for a varimax rotation. After the rotation, factor 1 has positive loadings for all elements except $\mathrm{Sr}$ and $\mathrm{Ca}$, while factor 2 has strong positive loadings for $\mathrm{Sr}, \mathrm{Zr}$, and $\kappa$ and negative loadings for indicates that the magnetic mineral assemblage is dominated by magnetite and that magnetic coercivity has a strong particle size dependence (Supplementary Figure S6), meaning that $\kappa_{\mathrm{ARM}} / \kappa$ can be interpreted as dominantly reflecting magnetic 'grain-size' or domain state variations (Banerjee et al., 1981; King et al., 1982). Accordingly, we interpret the sediment geochemical and magnetic variations as reflecting the relative concentration of sedimentary/carbonate rocks versus granitic/crystalline rocks (Factor 1) and sediment particle size (Factor 2) (Supplementary Figure S5b). Thus, in the sediment cores, we interpret magnetic susceptibility (both $\kappa$ and $\chi$ ) and $\mathrm{XRF} \mathrm{Ti} / \mathrm{Ca}$ ratios as tracers for the granitic/crystalline rocks sourced inland, beneath the Greenland Ice Sheet. the fjord and particle-size dependent transport processes. We first measured the $\chi$ of the $<4,4-63$, and $63-250 \mu \mathrm{m}$ fractions of the terrestrial samples listed in Supplementary Table S4, and then picked four samples that seemed to be representative of the variations for further analysis

454 (Figure 1). We find that catchment samples from Hall Land and Washington Land have low 455 concentrations of magnetic minerals in all size fractions, while uplifted poorly sorted 456 glaciomarine sediments in Hall Land are enriched in magnetic susceptibility in only the coarser 457 fractions (Supplementary Figure S5c-e). Sediments sampled directly from the left lateral 458 ablation zone of Petermann Glacier are enriched in magnetic minerals in the finer silt fractions, 459 while having low abundances in the sand fractions (Supplementary Figure S5f). We 
supplement these observations with samples from core 05UW, which are the closest sediments recovered to the Petermann grounding line and likely represent a mixture of sediments sourced to Petermann and Porsild Glaciers (see Figure 1). The core 05UW samples are also enriched in magnetic minerals in the finer silt fractions, with lower concentrations in the coarser silt and fine sand fractions (Supplementary Figure S5g-h). Compared with the particle size-specific $\chi$ of the more distal fjord sediments, we recognize that none of our 'source' samples have the high concentration of magnetic minerals observed in the coarser fractions (Supplementary Figure S5c-h).

Downcore records of particle-size specific $\chi$, as a tracer for the relative contribution of inland granitic/crystalline sourced rocks, offers the opportunity to link sediment province changes to specific glacio-marine depositional processes and can be measured on small sizefraction sample sizes. For example, changes in $\chi$ that occur predominantly in the coarser fraction may be linked to sediment delivered as IRD, while changes in $\chi$ that occur only in the finer fractions may be linked to sediment transported in the water column and deposited by suspension settling. The outer fjord splice was sampled at 15 intervals to capture variability observed in the bulk magnetic and XRF geochemical data. An additional 10 samples were taken from 04GC at the same correlated equivalent depths to ensure the observed signals were representative of broad scale signals. Particle-size-specific $\chi$ reveals systematic variations with respect to particle size and was reproducible between the cores, except where sample sizes were very small in the coarsest fractions (Figure 4). $\chi$ is very low in the $<4 \mu \mathrm{m}$ fraction in the marine sediment cores and terrestrial samples, indicating that fine silt- to sand-size particles have a greater influence on $\chi$ 
Using $\chi$ as a tracer for source, we employ an endmember model to isolate characteristic distributions of $\chi$ across the 4-150 $\mu \mathrm{m}$ particle size fractions, which can be used to evaluate relative source contributions to specific glaciomarine sedimentary processes (Figure 4). We choose a three-endmember model, as two endmembers do a poor job of fitting the data from 175$308 \mathrm{~cm}$ ced and four endmembers do not do a significantly better job of explaining variance (Figure 3k-m). The result are end-members that track relative source changes to the finer silt, coarser silt, and sand fractions. Most importantly, this illustrates that changes in bulk sediment $\mathrm{Ti} / \mathrm{Ca}$ and $\kappa$ are likely related to different processes above and below $200 \mathrm{~cm}$ ced in lithologic unit 1 . Above $200 \mathrm{~cm}$ the increased relative contribution of crystalline/granitic sources is related to changes in the finer silt fraction, while below $200 \mathrm{~cm}$ the changes are related to a change in composition of the coarser fractions.

\subsection{Using IRD Gradients to Reconstruct Past Ice Tongue Extents}

The spatial distribution of IRD in near-surface sediments recovered from Petermann Fjord demonstrates that the ice-tongue is a primary control on the spatial distribution of IRD deposited in the fjord. Little-to-no IRD is found below the ice tongue and there is a gradient in IRD within the pre-2010 historical ice tongue extents (Figure 3b). Using this observation, we reconstruct past ice-tongue extents by looking at the spatial distributions of downcore IRD concentrations on their ced scale.

Our first step was to create stacks with $4 \mathrm{~cm}$ ced bins of the $>2 \mathrm{~mm}$ index to improve signal to noise using cores from four distances from the Petermann grounding line: $25 \mathrm{~km}$ (02UW and 03UW), 52-56 km (08GC and 10PC), 68-71 km (04GC and 40PC/TC), and $80 \mathrm{~km}$ (03PC/TC and 41GC) (Figure 5a). 
Based on IRD concentrations in the upper $50 \mathrm{~cm}$ of each core (Figure 3a) and assuming these represent conditions like the historical record, we use concentrations greater than 0.03 clasts $/ \mathrm{cm}^{3}$ as representative of a depositional environment beyond the limit of the ice tongue and concentrations less than 0.005 clasts $/ \mathrm{cm}^{3}$ as representative of sub-ice tongue depositional environment. As our IRD record likely integrates decades to centuries and we know from the historical record that ice tongue lengths can vary by 10 s of $\mathrm{km}$ on these timescales (e.g., Falkner et al., 2011), we also assume that values between 0.005 and 0.03 clasts $/ \mathrm{cm}^{3}$ represent a depositional environment within the range of multi-decadal ice-tongue extents, like observed in the near-surface IRD concentrations.

We reconstruct ice tongue extents by estimating where the 0.005 and $0.03 \mathrm{clasts} / \mathrm{cm}^{3}$ position might be. If all sites have concentrations $>0.03$ clasts $/ \mathrm{cm}^{3}$, then we infer absence of an ice tongue at that time. If sites more proximal than others have $<0.03$ clasts $/ \mathrm{cm}^{3}$, we linearly interpolate using core location and IRD concentration to estimate where the 0.005 and 0.03 clasts $/ \mathrm{cm}^{3}$ position would be found and use those distances as the minimum and maximum ice tongue extents for that time slice. If all sites have less than .005 clasts $/ \mathrm{cm}^{3}$ we estimate the minimum extent but set the maximum extent arbitrarily at $90 \mathrm{~km}$ from the modern grounding line (Figure 5d).

The resulting reconstruction suggests that a paleo-ice tongue was present near the base of the stratigraphy and broke-up around $402 \mathrm{~cm}$ ced. The ice tongue was not reestablished until the upper $160 \mathrm{~cm}$ ced and did not reach historical extents until the upper $55 \mathrm{~cm}$ ced. Changes in icetongue configurations inferred from IRD are accompanied by changes in particle size specific sediment compositions (especially coarse silt and sand magnetic susceptibility) (Figure 6). This indicates that not all IRD in our IRD records are sourced to Petermann Glacier and that the 
relative amount of Petermann sourced IRD covaries with our reconstructed presence or absence of the Petermann Ice Tongue.

\subsection{Paleosecular Variation (PSV) and Sediment Core Chronology}

${ }^{14} \mathrm{C}$ dates for cores $41 \mathrm{GC}$ and $03 \mathrm{UW}$ display good agreement when transferred to their correlated equivalent depth scale except for one mixed-species benthic foraminiferal date in $41 \mathrm{GC}$ at $159-161 \mathrm{~cm}$ core depth $(188.72 \mathrm{~cm}$ ced $)$ which is older than a stratigraphically lower date at 166-168 cm (195.72 cm ced) on the single benthic species E. excavatum (Table 1). As the anomalously old date in core $41 \mathrm{GC}$ is also older than the $03 \mathrm{UW}$ date at $229-231 \mathrm{~cm}$, which we correlate to $173.02 \mathrm{~cm}$ ced and is in good agreement with all other dates in 41GC, we exclude the anomalous date from our age-depth modeling.

Comparison of ${ }^{210} \mathrm{~Pb}$-based accumulation rates and ${ }^{14} \mathrm{C}$ dates in $38 \mathrm{MC}$ suggest a considerable apparent radiocarbon age offset. Radiocarbon ages are on the order of 1200-1400 ${ }^{14} \mathrm{C}$ years ( $\Delta \mathrm{R}$ equivalent of roughly $800-1000$ years), which is older than expected ages for the last few decades when compared with regional estimates of $\Delta \mathrm{R}$ of a few hundred ( 200-300) years from Southern Nares Strait and Northern Baffin Bay for near surface waters (Coulthard et al., 2010) (Figure 7). While it is difficult to quantify an exact reservoir age from these postbomb dates, radiocarbon age offsets relative to ${ }^{210} \mathrm{~Pb}$ are likely quite large in Petermann Fjord. To further investigate the potential for similar age offsets in the older part of the stratigraphy, we compare PSV in Petermann Fjord cores to the WHAP18 template.

Petermann Fjord sediments in lithologic unit 1 display simple AF demagnetization behavior, with ChRM directions mostly plotting near expected inclination values based on the 
geocentric axial dipole $(\mathrm{GAD})$ hypothesis $\left(\right.$ Inclination $\left.=85^{\circ}\right)$ and with maximum angular deviation (MAD) values almost entirely less than $3^{\circ}$ (Supplementary Figure S7). Disturbed intervals and places where large IRD clasts were removed prior to sampling were removed from the paleomagnetic dataset before stacking. The most pronounced paleomagnetic feature has shallow inclinations around $200 \mathrm{~cm}$ ced (Figure 8f). As large changes in declinations can result from small angular changes at steep inclinations (e.g., at an inclination of $85^{\circ}$, a $4^{\circ}$ angular change can result in a $45^{\circ}$ declination swing), we rotate the declinations for each core by $85^{\circ}$ (04GC), $85^{\circ}$ (40TC), and $115^{\circ}(41 \mathrm{GC})$, based on the declination values in the interval of shallowest inclination and ARCH3k.1 model predictions (Korte et al., 2009). While this declination treatment strategy may not necessarily capture absolute declination values, it does allow us to compare relative declination changes useful for PSV stratigraphy. Alternate declination treatment strategies like arbitrarily rotating declinations to a mean of zero, as is often done for low to mid-latitude sites, yields poor agreement between the three Petermann Fjord cores.

The Northern North Atlantic and Chukchi Sea records have excellent agreement when projected to Petermann Fjord via their VGP paths. and 95\% of the circular standard errors in our WHAP18 Template, spanning 320 to $9000 \mathrm{cal}$ yrs BP, are between $3.1^{\circ}$ and $13^{\circ}$ with a median value of $6^{\circ}$ (Figure 8). The best agreement is between 840 and 5580 cal yrs BP, where $95 \%$ of the circular standard errors are between $2.9^{\circ}$ and $7.9^{\circ}$ with a median of $4.8^{\circ}$. The most prominent feature in the WHAP18 template is an inclination low of about $70^{\circ}$ around 2500 cal yrs BP, that occurs around the time of the $\mathrm{f}$ to e transition as defined in the British Master Curve (Thompson and Turner, 1979) and subsequently observed in the North Atlantic (Stoner et al., 2013, 2007) and Europe (Snowball et al., 2007). This interval roughly corresponds to high paleointensities in 
573 Europe (Genevey et al., 2008; Stoner et al., 2013) and shallow inclination in Western North

574 America and the Northeast Pacific (Hagstrum and Champion, 2002; Walczak et al., 2017).

When comparing the Petermann Fjord PSV Stack to the WHAP18 Template and, assuming that $\Delta \mathrm{R}$ is constant in time, we find the best agreement with a $\Delta \mathrm{R}=770 \mathrm{yrs}$ (Figure 9a; Table 2). We use this $\Delta \mathrm{R}$ for our preferred age model (M1; Figures 9a and 10a-c) but recognize there are many additional uncertainties that are difficult to quantify. One uncertainty is the choice of $\Delta \mathrm{R}$ for the marine records used to construct the stack; however, these regions have much better constraints on their $\Delta \mathrm{R}$ than Petermann Fjord and these uncertainties are likely minor in comparison to Petermann Fjord. To assess the potential impact of other uncertainties on our chronology, specifically on the timing of the events discussed in the main text, we run a series of sensitivity tests, summarized in Table 2 and discussed below.

One of the largest uncertainties in the application of PSV stratigraphy is our limited understanding of the sediment magnetic acquisition process. Laboratory tests and theoretical work suggest that a post-depositional remanent magnetization (pDRM) is acquired in a lock-in zone following deposition (Egli and Zhao, 2015; Irving and Major, 1964; Løvlie, 1976; Verosub, 1977), although study of the mechanisms and sedimentary processes that are important for remanence acquisition is still an active area of research. Where independent stratigraphic control and/or superposition allow comparison, studies have found evidence for little or no offset (Valet et al., 2014), offsets of about 15-25 cm (Channell and Guyodo, 2004; Simon et al., 2018; Stoner et al., 2013; Suganuma et al., 2010), or larger offsets (Snowball et al., 2013). The records used to construct the reference WHAP18 template were deposited at sediment accumulation rates $\sim 100+$ $\mathrm{cm} / \mathrm{ka}$ and we assume that offsets in the magnetic and sediment ages are negligible. However, the Petermann Fjord cores, which have lower sedimentation rates (averaging $\sim 60 \mathrm{~cm} / \mathrm{ka}$ for the 
last $\sim 7 \mathrm{ka}$ on the M1 age model), could have a more significant offset in age. We test this impact in our M2 age-depth model by offsetting the Petermann PSV by $20 \mathrm{~cm}$. The result is a younger optimized $\Delta \mathrm{R}$ of $570 \mathrm{yrs}$, which pushes age estimates for key horizons up to a few hundred years older (Figures 9b and 10d-f; Table 2). While this is a significant difference, it does not change our overall interpretation in our discussion, which is based on long-term trends from the Middle to late Holocene.

$\Delta \mathrm{R}$ may vary systematically through time, both in the Petermann region and in the WHAP18 template records. To account for this uncertainty, our M3 age-model uses a standard $604 \Delta \mathrm{R}$ uncertainty of $\pm 200 \mathrm{yrs}$. The optimized $\Delta \mathrm{R}$ is $800 \mathrm{yrs}$, which is only a slight difference from our preferred model's optimized choice (Figure 9c; Table 2). The biggest difference is the change in the uncertainty structure of the resulting age models, with the biggest impact close to the age control point depths. feature controlling the optimized $\Delta \mathrm{R}$ choice in the M1-M3 age-depth models; away from this feature, PSV correlations are less robust. Accordingly, we run our final sensitivity tests, starting 611 with the M4 age-models, by prescribing a $\Delta \mathrm{R}$ of $750 \pm 500$ years which creates a very wide 612 uncertainty structure. We then generate 100,000 iterations of the M4 age model, but only accept 613 the best 1,000 PSV fits, quantified as the mean cosine distance of the overlapping time series, for 614 the final results. As expected, age control is best constrained where the highest amplitude PSV 615 feature is and uncertainty is much greater where PSV features are lower amplitude (Figure 10b616 c; Table 2). While this age model changes the uncertainty structure and may offer insight to unresolved sedimentation rate changes, it agrees within statistical uncertainty with our preferred age model (M1) and would not change our overall interpretation. For comparison, we repeat the 
same experiment applying a magnetic lock-in depth of $20 \mathrm{~cm}$ and $\Delta \mathrm{R}$ of $500 \pm 500$ yrs to generate the M5 age model (Figure 10e-f; Table 2). Like the M4 age model, the M5 age model changes the uncertainty structure of the age-depth relationship but is within statistical uncertainty of the M2 age model.

We recommend using the radiocarbon based M1 age model, which uses a constant reservoir age constrained by PSV stratigraphy, for future studies and regional comparisons. The uncertainty estimates of the M1 age model quantifies the precision of the age given our assumptions and the positions of our age control points. However, when making sub-millennial comparisons, our sensitivity tests suggest that geologic uncertainties inherent to radiocarbon reservoir ages and magnetic acquisition processes are not fully quantified and may account for difference of a few hundred years.

\subsection{Conceptual Depositional Model for Petermann Fjord}

Three depositional processes are the most apparent in the stratigraphic record of Petermann Fjord: suspension settling from the water column, IRD (transported by sea-ice or iceberg), and gravity flows (Supplementary Figure S8). While reworking of sediment by currents or tides may also play a role, we have no evidence of its importance at this stage.

\subsubsection{Well-sorted Coarse Deposits}

The well-sorted coarse deposits found in select cores are interpreted to be gravity flow deposits and/or suspension settling from nearby sourced turbid melt-water plumes. Beneath the Petermann Ice Tongue, these deposits dominate the stratigraphy of 05UW, 06UW, and 07UW, 
641 but are absent in 02UW and 03UW, indicating that they are only deposited in the deeper "inner

642 basin', bound by the 'inner sill' of Tinto et al. (2015) and the Petermann grounding line. Similar

643 facies have been observed in grounding-line proximal basins beneath paleo-ice shelves on the

644 Antarctic Peninsula (Christ et al., 2014; Evans and Pudsey, 2002; Reilly et al., 2016) and in

645 basins proximal to tidewater glaciers by a variety of depositional processes (Domack, 1990; Ó

646 Cofaigh and Dowdeswell, 2001). The Ti-rich bulk sediment composition and high fine-silt $\chi$ of

647 these layers suggest they may reflect the dynamics of the Petermann grounding-line, however we

648 cannot fully rule out influence from the smaller Porsild Glacier (Figure 1) that also terminates

649 near the inner-basin. Seaward of the inner sill, the Ca-rich composition of the other well-sorted

650 coarse deposits observed are interpreted as reflecting the dynamics of the smaller marine

651 terminating glaciers in the fjord, like Belgrave Glacier near 37PC, or mass wasting events of the

652 fjord walls, as documented by Jakobsson et al.(2018) (Supplementary Figure S2).

\section{$654 \quad 3.5 .2$ Ice Rafted Debris}

655 Poorly sorted coarse material found in a finer grained sediment matrix is interpreted as

656 IRD in lithologic units 1 and 2 (Figure 2). We consider four sources of IRD: icebergs sourced to

657 the Petermann Ice Tongue, icebergs sourced to Petermann Fjord tidewater glaciers, icebergs

658 sourced externally from the fjord, and coarse material transported by sea ice. The glacial ice

659 likely entrains the majority of its sediment in its basal ice (Alley et al., 1997) which is generally

660 thought to be the most important contributor to IRD fluxes (Andrews, 2000), with observations

661 and estimates from other systems indicating order of magnitude higher sediment concentrations

662 than ice outside of the basal debris layer (Ashley and Smith, 2000; Dowdeswell and

663 Dowdeswell, 1989; Syvitski et al., 1996). Additional sediment can be sourced from supraglacial 
664

debris or entrained during medial or lateral moraine formation. For discussion later, this will be referred to as englacial sediments as opposed to basal sediments.

The Petermann ice tongue is a primary control on the distribution of IRD, as clearly seen in the distribution of coarse material in the uppermost sediments throughout the fjord (Figure 3b). While it is possible that some IRD is deposited beneath the ice tongue itself at our coring locations, it seems that this is a rare occurrence. Sea ice could also be an important source of IRD seaward of the ice tongue, as we observed sea ice in the fjord with high concentrations of poorly sorted material during the expedition, which we interpret as reflecting mass wasting events of the steep fjord walls (Supplementary Figure S9). IRD was also observed in icebergs, seaward of the ice tongue, which were sourced to the smaller tidewater glaciers that terminate in the fjord or to the ice tongue itself. Sediments present in the ice tongue or in ice tongue calved bergs, are likely englacial or supraglacial sourced, as the debris entrained in basal ice is thought to be deposited close to the grounding line during melting (Alley et al., 1989) where melt rates are the highest (Cai et al., 2017; Münchow et al., 2014; Rignot and Steffen, 2008). Our best estimate of the composition of the Petermann ice tongue sourced supraglacial/englacial sediment comes from our lateral ablation zone terrestrial sample (p15-EM-03), which suggests that while the fine material is enriched in high $\chi$ crystalline/granitic sources, the coarse material is primarily composed of low $\chi$, carbonate/sedimentary sources (Supplementary Figure S5). These observations suggest past changes to ice tongue length or absence of the ice tongue would have a significant impact on the abundance, distribution, and composition of IRD deposited in the fjord. In lithologic unit 3, found at the base of 03PC, 06PC, 10PC, and 40PC, coarse material is likely not IRD and instead represents deposits formed close to grounded ice, where melt rates are high, but the exact nature of these deposits needs to be investigated further (Figure 2). 


\subsubsection{Suspension Settling}

Transport of fine sediments in the water column is also an important depositional process as some of the lithologies observed show little or no evidence for IRD or gravity flows. While no turbidity measurements were made in the water column during The Petermann 2015 Expedition, sediment-rich turbid layers were visually observed using a GoPro camera attached to the UWITEC coring system while coring beneath the ice tongue (Supplementary Movie S1) and

694 quantified as function of backscatter in the video (Washam et al., in review). While sediments

695 transported beneath ice shelves in pulsed meltwater plumes have been assumed to be an 696 important process where small fjord paleo-ice shelves are inferred (e.g., Christ et al., 2014; Reilly et al., 2016), observations of high turbidity layers near the surface, in the water column, or near the sea floor are based on oceanographic measurements near ice-shelf free marine terminating glaciers (Ashley and Smith, 2000; Cowan and Powell, 1990; Domack and Ishman, 1993; Jaeger and Koppes, 2016; Syvitski et al., 1996). In Petermann Fjord, backscatter calculated from the GoPro video suggests the highest concentrations of suspended sediments in meltwater within $20 \mathrm{~m}$ of the base of the ice tongue (Washam et al., in review). Seaward of the ice tongue, meltwater in Petermann Fjord was observed in 2015 at highest concentrations at about $150 \mathrm{~m}$ water depth seaward of the ice tongue edge (Heuzé et al., 2016); however, turbidity measurments are still needed to assess concentrations of suspended sediments in the water column. IRD free,

706 fine-grained facies, particularly lithologic unit 1A at sub-ice tongue locations, indicates the 707 importance of deposition by suspension settling from sediment sourced to Petermann Glacier transported in the water column. 


\section{Discussion}

\subsection{The Recent Ice Tongue Facies in the Uppermost Stratigraphy}

We assume that the lithologic Subunit 1A (Figure 2) reflects depositional processes with

714 an ice tongue like that observed in the historical record. In the upper $50 \mathrm{~cm}$ of the cores, we observe along-fjord gradients in the degree of bioturbation traces (Figure 3d-e; Supplemental Figure S3). More diffuse contacts and increased low-density burrow features in the outer fjord indicate enhanced bioturbation, likely due to greater organic rain as food supply to the benthos associated with open water outside and near the ice front and no significant spatial gradients in accumulation rate as unit thickness is consistent. The sub-ice tongue cores taken closest to the modern grounding zone are laminated, banded, and lack bioturbation suggesting a depositional environment in which sediment flushed by subglacial meltwater is deposited both by rain-out of fine materials from buoyant plumes, and intermittent downslope gravity flows from a grounding zone sedimentary wedge (Supplementary Figures S2-S3). The ratio of these elements tracks the contribution of carbonate and Paleozoic sedimentary rocks that comprise the local surficial geology (Dawes et al., 2000a), relative to sediments derived from igneous crystalline rocks. Quartz and feldspar-rich pink granite and other Ti enriched rocks were observed locally on land only as glacial erratics that must originate from inland sub-ice sources (Reusche et al., 2018). Thus, Ti/Ca and magnetic susceptibility (Supplementary Figure

730 S5) can be interpreted as tracers for sediments entrained in basal ice from Petermann Glacier. 
We also observe a spatial pattern in the upper $\sim 50 \mathrm{~cm}$ unit for $>2 \mathrm{~mm}$ clast concentration, interpreted in this lithologic unit to reflect IRD (Figure 3b). In the sediment sampled from underneath the historical ice tongue (i.e., that present prior to 2010 , with a front $\sim 70 \mathrm{~km}$ from the grounding zone), > $2 \mathrm{~mm}$ IRD clasts are essentially absent. Seaward of the historical ice front, IRD concentrations increase. This is consistent with the hypothesis that ice shelves act as a debris filter (e.g., Alley et al., 2005) and depositional models (e.g., Domack and Harris, 1998) in which basal ice entrains high quantities of subglacial sediment (Alley et al., 1997) which is removed by rapid basal melting of the ice shelf near the grounding zone (Cai et al., 2017; Rignot and Steffen, 2008). While we observed supraglacial and englacial sediment, likely entrained from medial and lateral moraines, these sediments are mostly located near the edge of the ice tongue, and would be smaller contributors to the flux of IRD compared to sediments entrained by basal ice (Andrews, 2000). Video evidence from through-ice boreholes reveal that the ice comprising the ice tongue is remarkably clean and devoid of clasts or sediment (Supplementary Movie S1). Coarse material obtained from the left lateral moraine has a low abundance of the high magnetic susceptibility crystalline material (Supplementary Figure S5), suggesting its derivation from local sedimentary country rock and providing further support that magnetic susceptibility is a reliable tracer of crystalline basement rocks entrained in basal ice.

\subsection{Petermann Glacial History Inferred from Fjord Stratigraphy}

Down-core variations of these sedimentologic and geochemical properties constrain past changes of the Petermann Ice Tongue (Figure 6). Changes in the ice tongue extent are inferred from the concentration of $>2 \mathrm{~mm}$ clasts, $\mathrm{Ti} / \mathrm{Ca}$, and the $\chi$ of nine particle size fractions, the later 
753

which traces the fraction of crystalline basement materials in the context of particle sizedependent depositional processes.

The lowermost (oldest) recovered sediments are glacial diamicts, likely deposited near grounded ice after the abrupt retreat from the outer fjord sill (Jakobsson et al., 2018), but are likely not subglacial till, as they are not overly compacted (Unit 3; Figure 2). Above this unit are IRD-poor laminated sediments, which record the presence of an extensive ice tongue that existed following retreat from the outer fjord sill (Unit 2; Figure 2). The preservation of laminae indicates a lack of bioturbation and/or high accumulation rates, suggesting a great distance between this site and the floating ice front or open water, and perhaps proximity to a paleo grounding zone. This is likely to be the 540-610 m water depth bedrock-cored inner sill located about $25 \mathrm{~km}$ seaward of the modern grounding zone, which has been identified by geophysical surveys (Tinto et al., 2015) (Figure 1; Figure 6f-g). This inference is also supported by higher magnetic susceptibility in the coarse silt fraction than in near surface IRD-poor sediments, suggesting a coarser grain size for Petermann crystalline basement sourced material and, in turn, increased proximity to the Petermann sourced turbid meltwater layers (Figure 4).

The abrupt appearance of IRD clasts around $402 \mathrm{~cm}$ ced reveal that the paleo-ice tongue broke-up, and that seasonally-open marine conditions with no stable ice tongue persisted to around $160 \mathrm{~cm}$ ced (Subunit 1C), when a less extensive ice tongue (i.e., with diminished but not absent IRD in the middle fjord) reformed (Subunit 1B; Figures 2 and 6). The newly established ice tongue only reached stable pre-2010 historical extents (i.e., with IRD absent in the middle fjord) in the upper $55 \mathrm{~cm}$ ced (Subunit 1A). Following the paleo-ice tongue break-up, we observe a significant change in the composition of IRD, with IRD enriched in crystalline basement sourced sediments, indicating inclusion of basal ice in Petermann calved icebergs (Figures 4 and 
6). The relative contribution of sediments sourced from crystalline basement in the coarse fraction reduces to negligible values when IRD becomes rare, consistent with initiation of the floating ice tongue as a basal ice debris filter. Meanwhile, the relative proportion of sediments sourced from crystalline basement increases in the fine silt fraction, indicating a change in sediment flux or transport processes with the onset of the new ice tongue, perhaps via channeling of buoyant meltwater plumes emanating from the grounding zone (Figure 6).

\subsection{The Chronology and Regional Context of Petermann's Glacial History}

After applying our multi-proxy chronology (M1 age model used in this discussion; Table 2), the timing of ice tongue changes can be used to investigate the stability of Petermann Glacier and its ice tongue in relationship to paleoenvironmental conditions-particularly the conditions needed to prevent a stable ice tongue from forming $(\sim 160-402 \mathrm{~cm}$ ced $)$ and to rebuild and maintain a 70-90 km long ice tongue (i.e., consistent with pre-2010 extents; $\sim 0-55 \mathrm{~cm}$ ced) (Figure 11).

Petermann's floating ice tongue broke-up $\sim 6.9 \mathrm{ka}( \pm 1 \sigma$ range: $6.8-7.0 \mathrm{ka})$, with our sedimentological and provenance data indicating an abrupt collapse. This break-up lagged the warmest Holocene temperatures as inferred from the nearby Agassiz ice core or nearby lake sediments (Figure 1; Lecavalier et al., 2017; McFarlin et al., 2018). However, the sediments in Petermann Fjord only contain a history of Petermann Glacier following the glacier's retreat from the outer sill a few centuries earlier, which was the last of a series of deglacial events inferred from the seafloor bathymetry of Nares Strait (Jakobsson et al., 2018). Nares Strait glacial histories suggest deglaciation was underway for millennia prior to the start of our record and likely included a series of retreats (Bennike, 2002; England, 1999; Georgiadis et al., 2018; 
Jakobsson et al., 2018; Jennings et al., 2019, 2011; Reusche et al., 2018; Zreda et al., 1999). The $\sim 6.9 \mathrm{ka}$ ice tongue break-up documented here was one of the final events of the early Holocene deglaciation. The earlier transition from lithologic Unit 3 to Unit 2 is only constrained by occurring after the retreat of Petermann Glacier form its grounded position at the outer sill in Hall Basin ( 7.5 ka) and prior to this ice tongue break-up.

Initial reestablishment of a small ice tongue began around $2.2 \mathrm{ka}( \pm 1 \sigma$ range: $1.9-2.3 \mathrm{ka})$, indicating almost five thousand years where paleoenvironmental conditions were unfavorable for the reformation of the ice tongue. From 6.9 to $2.2 \mathrm{ka}$, decadal mean surface air temperatures (Lecavalier et al., 2017) were $0.8-2.9^{\circ} \mathrm{C}$ warmer (95\% interval) than preindustrial times (defined here as $1750 \mathrm{CE}$ ) (Figure $11 \mathrm{~b})$. The trend of these temperatures, as reconstructed from the Agassiz Ice Core, is consistent with independently derived temperature estimates of maximum seasonal temperatures from Northwest Greenland lakes (Axford et al., 2019; Lasher et al., 2017).

811 While it is possible that warmer subsurface marine waters co-occurred with higher air

812 temperatures, the atmospheric warming alone would increase surface melting on Petermann 813 Glacier. Accordingly, the flux of sub-glacial run-off would increase, amplifying subglacial run814 off driven melt rates near the grounding zone through entrainment of warmer AW seawater in 815 buoyant plumes and, as a result, strengthen the circulation of the fjord (e.g., Cai et al., 2017; 816 Washam et al., in review). Additionally, while shore-based studies suggest extensive land-fast 817 sea ice in Northern Ellesmere Island and Greenland, driftwood deposition continued in the 818 Clements Markham Inlet (Ellesmere Island) until 3.5 cal ka BP (England et al., 2008; Funder 819 et al., 2011) (Figure 11c). From this, we infer relatively mobile sea-ice in the Lincoln Sea and 820 Nares Strait, which would alter wind stress on surface Nares Strait waters and increase Ekman 821 transport of subsurface AW into the fjord (e.g., Shroyer et al., 2017). Thus, a combination of 
decreased sea ice and higher atmospheric temperatures likely prevented the reestablishment of a stable ice tongue from $6.9-2.2 \mathrm{ka}$.

The reestablishment of a small Petermann Ice Tongue occurred during long-term regional cooling of the middle to late Holocene and followed the onset of heavier sea-ice in the Lincoln Sea (England et al., 2008; Lasher et al., 2017; Lecavalier et al., 2017). A stable ice tongue with an extent similar to pre-2010 historical observations was not established until about $0.6 \mathrm{ka}( \pm 1 \sigma$ range: $0.4-0.9 \mathrm{ka}$ ), when regional air temperatures reached their coolest values of the Holocene (Figure 11).

831 independent cosmogenic ages from lateral moraine deposits on the Petermann Glacier margins

832 with ages of $2.8 \pm 0.3 \mathrm{ka}$ and $0.3 \pm 0.2 \mathrm{ka}$ (Figure 11e; Reusche et al., 2018) and broadly

833 consistent with insolation driven late Holocene Northern Hemisphere Neoglacial cooling 834 culminating in maximum Little Ice Age glacial extents (Kaufman et al., 2009; Marcott et al., 835 2013). Further to the south in Northwest Greenland, there is also evidence for a smaller

836 Greenland Ice Sheet in the middle Holocene with lower reconstructed elevations than present at 837 the Camp Century ice core roughly between 6-3 ka (Lecavalier et al., 2017) and recently exposed

$838{ }^{14} \mathrm{C}$ dated plant material indicating a retreated ice margin around 4.7 ka (Farnsworth et al., 2018).

839 Further to the south in West Greenland, near Jakobshavn Isbræ, there is evidence that following 840 deglaciation margins of the Greenland Ice Sheet were smaller than present until they advanced 841 around $2.3 \mathrm{ka}$ and $0.4 \mathrm{ka}$ (Briner et al., 2010). The interval during which we infer the lack of a 842 floating ice tongue also aligns with the timing of human occupation of the region; the long-lived 843 Independence I and II cultures of Northern Greenland were only present before the 
reestablishment of the smaller ice tongue around $2.2 \mathrm{ka}$ (Grønnow and Jensen, 2003) (Figure 11d). potential insight into the short-term future of the ice-tongue. $20^{\text {th }}$ and $21^{\text {st }}$ century warming is amplified in the High Arctic, reversing an insolation-driven Holocene cooling trend, with modern regional temperatures warmer than those of the past $6.8 \mathrm{ka}$, as reconstructed from the nearby Agassiz Ice Core (Lecavalier et al., 2017). Estimated warming between 1982-2011 for

851 North Greenland is $2.7 \pm 0.3{ }^{\circ} \mathrm{C}$ relative to the $1900-1970$ average, with decadal mean

852 temperatures at levels of the warmest anomalies since $1750 \mathrm{CE}$ preindustrial times (Orsi et al., 853 2017). Models project additional warming in North Greenland of $1.5-3.0^{\circ} \mathrm{C}(\mathrm{RCP} 4.5)$ or $2.0-3.5$

$854{ }^{\circ} \mathrm{C}(\mathrm{RCP} 8.5)$ by 2050 (Fettweis et al., 2013). Based on the middle Holocene as an analog, Arctic 855 regional temperatures may have already passed the threshold of Petermann Ice Tongue stability,

856 and almost certainly will by 2050, suggesting that break-up of the existing ice tongue is

857 imminent. While it is still uncertain what the dynamic response of the grounded portions of

858 Petermann Glacier will be following future ice tongue loss (e.g., Nick et al., 2013), the

859 modification of fjord circulation without an ice tongue is projected to increase melt rates near the 860 grounding zone by an order of magnitude (Cai et al., 2017) and removal of the buttressing effect 861 of the thickest floating ice within $12 \mathrm{~km}$ of the grounding zone is projected to increase inland 862 glacial velocities significantly (Hill et al., 2018). 
864

865

866

867

868

869

870

871

872

873

874

875

876

877

878

879

880

881

882

883

884

885

\section{Conclusion}

Using a suite of sediment cores collected from Petermann Fjord during the Petermann 2015 Expedition, we find that the Petermann Ice Tongue only reached stable lengths consistent with historical observations about 600 years ago, when regional air temperatures were the coolest of the Holocene. The Petermann Ice Tongue was absent for almost 5 thousand years in the middle Holocene when ice core reconstructed decadal mean surface air temperatures were 0.8$2.9{ }^{\circ} \mathrm{C}$ warmer than pre-industrial (1750 C.E.) (Lecavalier et al., 2017). As the Petermann Ice Tongue is particularly sensitive to surface air temperature driven subglacial run-off melting (Cai et al., 2017; Washam et al., in review), this observation provides new insight to temperature thresholds of Petermann Ice Tongue stability. Recent regional warming has reversed the region's long-term insolation driven Holocene cooling and is projected to pass this temperature threshold by the mid- $21^{\text {st }}$ century, suggesting the Petermann Ice Tongue is at increasing risk of break-up.

\section{Acknowledgements}

We thank the Swedish Icebreaker Oden captain and crew and the Petermann 2015 Expedition scientific party; Paul Anker, Michael Brian, and Peter Washam for recovering cores beneath the ice tongue; the Oregon State University Marine and Geology Repository for core archival and help sampling; Stefanie Brachfeld, Bernard Housen, and Robert Wheatcroft for generous use of their laboratories; Jason Wiest for help with CT scanning; and two anonymous reviewers for their thoughtful and constructive reviews. The Petermann 2015 Expedition (OD1507) and this work was funded by the National Science Foundation Office of Polar Programs (Awards 1418053 to AM and JS, 1417787 to LM, and 1417784 to AJ), the Swedish 
886 Polar Research Secretariat, and a Swedish Research Council (VR) grant to MJ. Additional

887 support to BR came from Leslie and Mark Workman at the Oregon ARCS Foundation and a

888 Geological Society of America graduate student research grant. Paleomagnetic data are archived

889 with the Magnetics Information Consortium (MagIC) (Contribution:

890 http://www.earthref.org/MagIC/16535).

891

892 Appendix A: Supplementary Materials

893

Additional tables, figures, and a movie are available as supplementary materials.

894 


\section{Tables}

896 Table 1. Radiocarbon results. Dates in italics are not used in the age-depth model, as discussed 897 in the text.

\begin{tabular}{|c|c|c|c|c|c|c|c|c|}
\hline Core & $\begin{array}{r}\text { Core } \\
\text { Depth }(\mathrm{cm})\end{array}$ & $\begin{array}{l}\text { Correlated } \\
\text { Equivalent } \\
\text { Depth }(\mathrm{cm})\end{array}$ & Material & $\begin{array}{l}\delta^{13} \mathrm{C} \\
(\% \circ)\end{array}$ & ${ }^{14} \mathrm{C}$ Age & $\begin{array}{r}{ }^{14} \mathrm{C} \text { Error } \\
(1 \sigma)\end{array}$ & S-ANU\# & ANU N\# \\
\hline 03UW & $52-54$ & 40.87 & Mixed Benthics & -1.2 & 1421 & 26 & 56605 & 18414 \\
\hline 03UW & $229-231$ & 173.02 & Mixed Benthics & -2.2 & 3427 & 27 & 56606 & 18415 \\
\hline $38 M C$ & $9-10$ & - & Mixed Planktonics & 1.08 & 1375 & 33 & 53518 & 17241 \\
\hline $38 \mathrm{MC}$ & $9-10$ & - & Mixed Benthics & -0.07 & 1211 & 35 & 53519 & 17242 \\
\hline $38 M C$ & $9-10$ & - & C. neoteretis & 2.31 & 1298 & 45 & 53520 & 17243 \\
\hline $41 G C$ & $62-64$ & 91.72 & Mixed Benthics & -1.65 & 2578 & 33 & 53517 & 17240 \\
\hline $41 G C$ & $159-161$ & 188.72 & Mixed Benthics & -5.92 & 4077 & 26 & 53021 & 17226 \\
\hline $41 G C$ & $166-168$ & 195.72 & E. excavatum & -1.82 & 3567 & 26 & 56603 & 18423 \\
\hline $41 G C$ & $292-296$ & 322.72 & N. pachyderma (s) & -1.7 & 5697 & 30 & 56604 & 18423 \\
\hline $41 G C$ & $374-376$ & 403.72 & C. neoteretis & -1.4 & 7174 & 53 & 53516 & 17239 \\
\hline
\end{tabular}

898 
899 Table 2. Results of age-depth modeling sensitivity tests. The details for each model are

900 described in the text. Median ages (cal yrs BP) of key horizons are reported for each test with

901 their $\pm 1 \sigma$ uncertainties in parentheses (rounded to the nearest decade). The three depths used here 902 are the depths of the paleo-ice tongue collapse $(404 \mathrm{~cm})$, ice tongue reestablishment $(160 \mathrm{~cm})$, and growth to stable extents like those observed in the historical record $(55 \mathrm{~cm})$.

904

\begin{tabular}{|c|c|c|c|c|}
\hline Description & $\begin{array}{l}\text { Optimized } \\
\Delta R \text { (yrs) }\end{array}$ & $402 \mathrm{~cm}$ Age & $160 \mathrm{~cm}$ Age & $55 \mathrm{~cm}$ Age \\
\hline M1. Preferred Age Depth Model & 770 & $\begin{array}{c}6900 \\
(6820-6980)\end{array}$ & $\begin{array}{c}2180 \\
(1930-2300)\end{array}$ & $\begin{array}{c}590 \\
(390-920)\end{array}$ \\
\hline M2. Like M1, but with $20 \mathrm{~cm}$ magnetic lock-in offset & 570 & $\begin{array}{c}7140 \\
(7060-7220)\end{array}$ & $\begin{array}{c}2450 \\
(2180-2590)\end{array}$ & $\begin{array}{c}780 \\
(570-1160)\end{array}$ \\
\hline $\begin{array}{l}\text { M3. Like M1, but including a 200-year uncertainty on } \\
\Delta R\end{array}$ & 800 & $\begin{array}{c}6780 \\
(6500-7040)\end{array}$ & $\begin{array}{c}2050 \\
(1790-2290)\end{array}$ & $\begin{array}{c}580 \\
(320-940)\end{array}$ \\
\hline $\begin{array}{l}\text { M4. Like M1, but prescribing } 750 \mathrm{yr} \Delta \mathrm{R} \pm 500 \mathrm{yr} \\
\text { uncertainty and optimizing fit to PSV }\end{array}$ & $\mathrm{N} / \mathrm{A}$ & $\begin{array}{c}6510 \\
(6060-6980)\end{array}$ & $\begin{array}{c}2020 \\
(1740-2250)\end{array}$ & $\begin{array}{c}620 \\
(300-1040)\end{array}$ \\
\hline $\begin{array}{l}\text { M5. Like M4, but prescribing } 500 \mathrm{yr} \Delta R \pm 500 \mathrm{yr} \text { with } \\
\text { a } 20 \mathrm{~cm} \text { magnetic lock-in offset }\end{array}$ & N/A & $\begin{array}{c}6940 \\
(6460-7440)\end{array}$ & $\begin{array}{c}2420 \\
(2280-2540)\end{array}$ & $\begin{array}{c}480 \\
(270-750)\end{array}$ \\
\hline
\end{tabular}




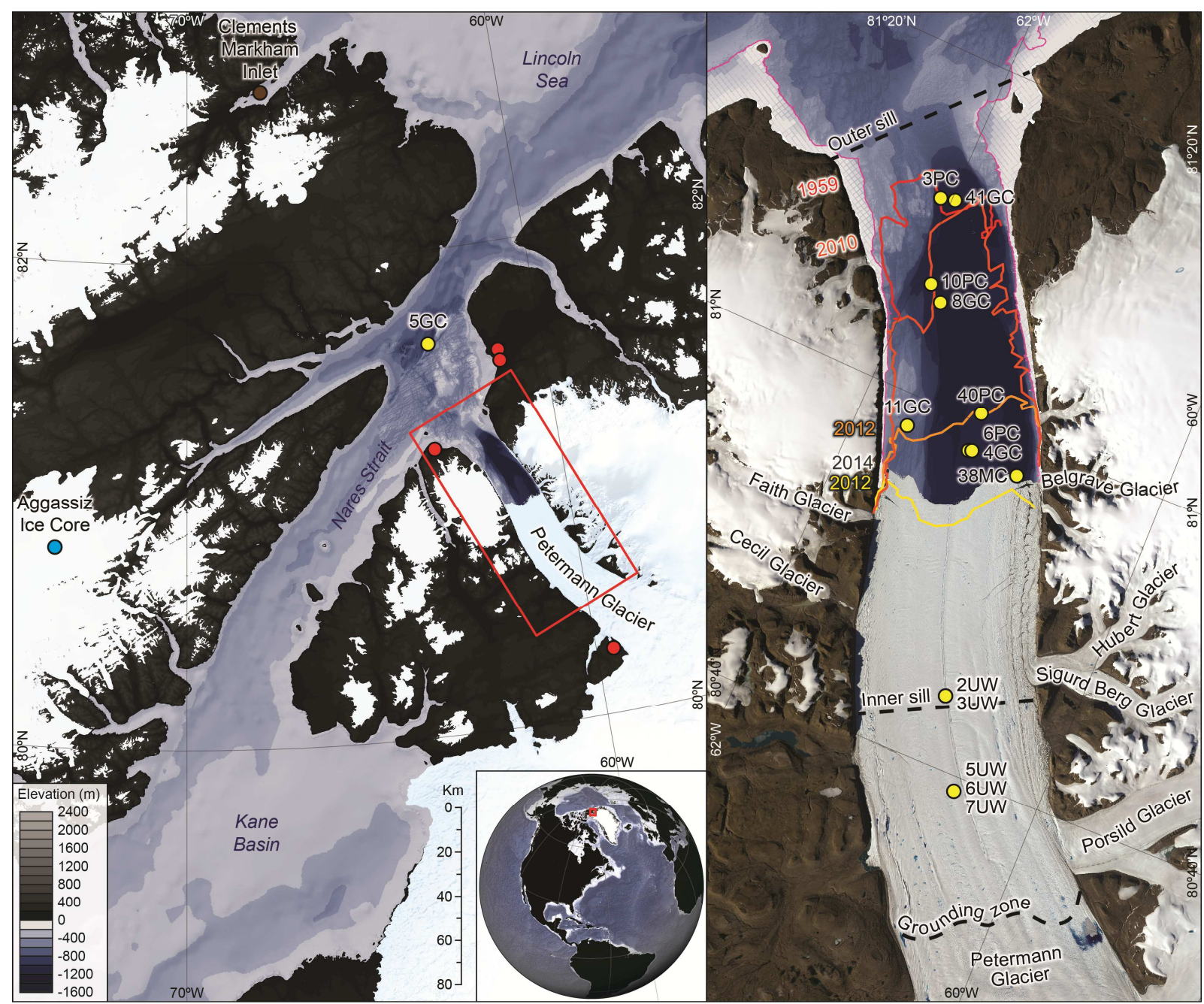

Figure 1. Overview map and coring locations. Left, overview of region indicating Petermann Fjord (red box), terrestrial sediments used to characterize source materials (red dots), the HLY0301-05GC core from Nares Strait (yellow dot; Jennings et al., 2011), the Agassiz ice core (blue dot; Lecavalier et al., 2017), and the Clements Markam Inlet (brown dot; England et al., 2008). Right, locations of sediment cores recovered from Petermann Fjord during The S1). Past ice tongue extents are indicated for 1959 (red), 2010 prior to that year's calving event (dark orange), 2012 prior to that year's calving event (light orange), and 2012 following that year's calving event (yellow). Landsat 8 OLI image from August 11, 2014. Bathymetry in Petermann Fjord from Jakobsson et al. (2018) overlain over IBAO v3 (Jakobsson et al., 2012). 


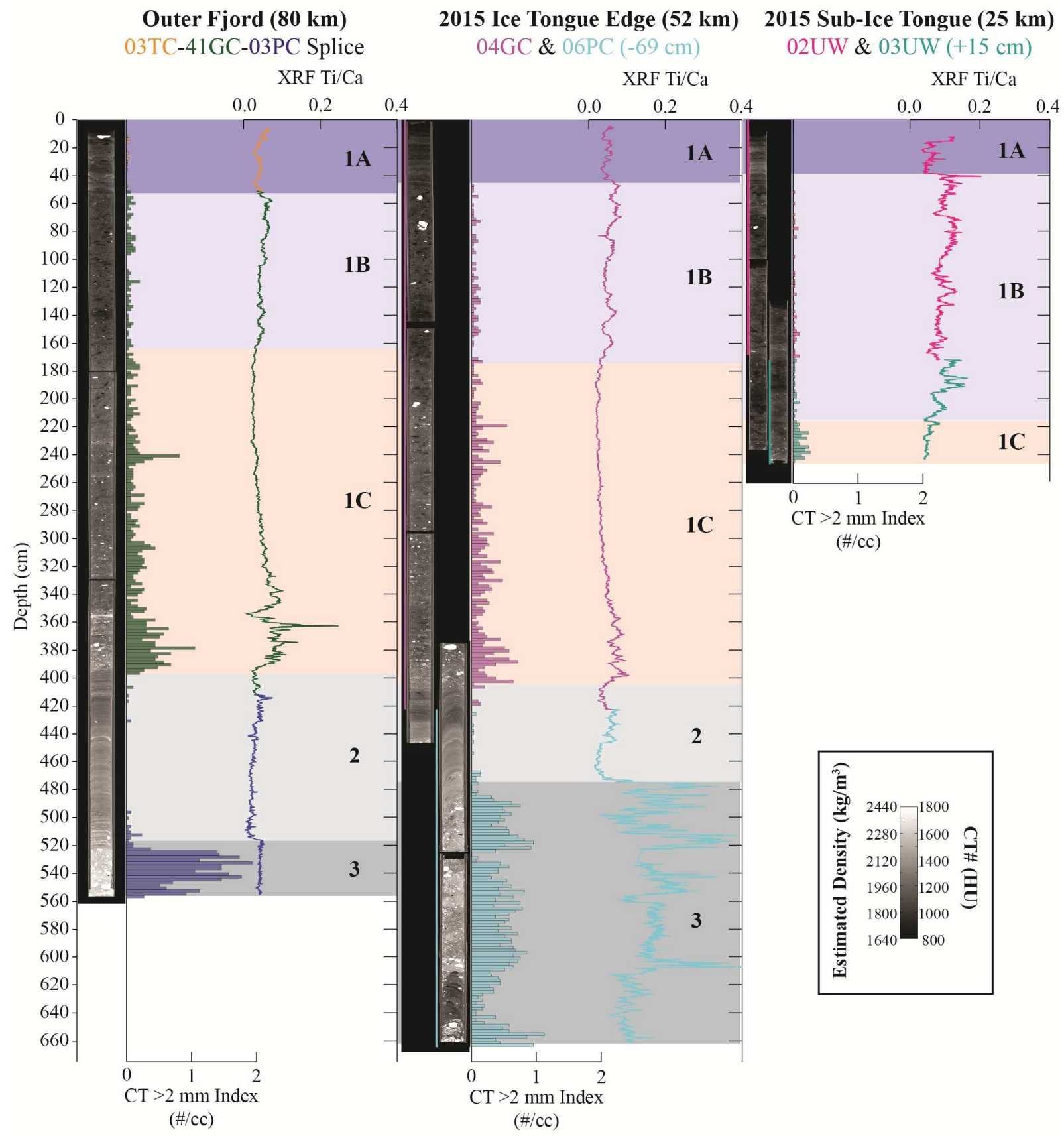

Figure 2. Petermann Fjord stratigraphy. CT scan slices, CT $>2 \mathrm{~mm}$ clast index, and XRF $\mathrm{Ti} / \mathrm{Ca}$ ratios for cores recovered at three locations in the fjord: 80,52 and $25 \mathrm{~km}$ from the Petermann grounding zone. The outer fjord is represented as the outer fjord splice (Supplementary Figure S1; Supplementary Table S2), while the other two locations are represented by two cores, with the deeper core offset to align a lithologic transition captured in both cores. Sections 4 and 5 for 06PC are plotted despite significant coring deformation, as they capture what are likely some of the oldest sediments recovered from the fjord. 

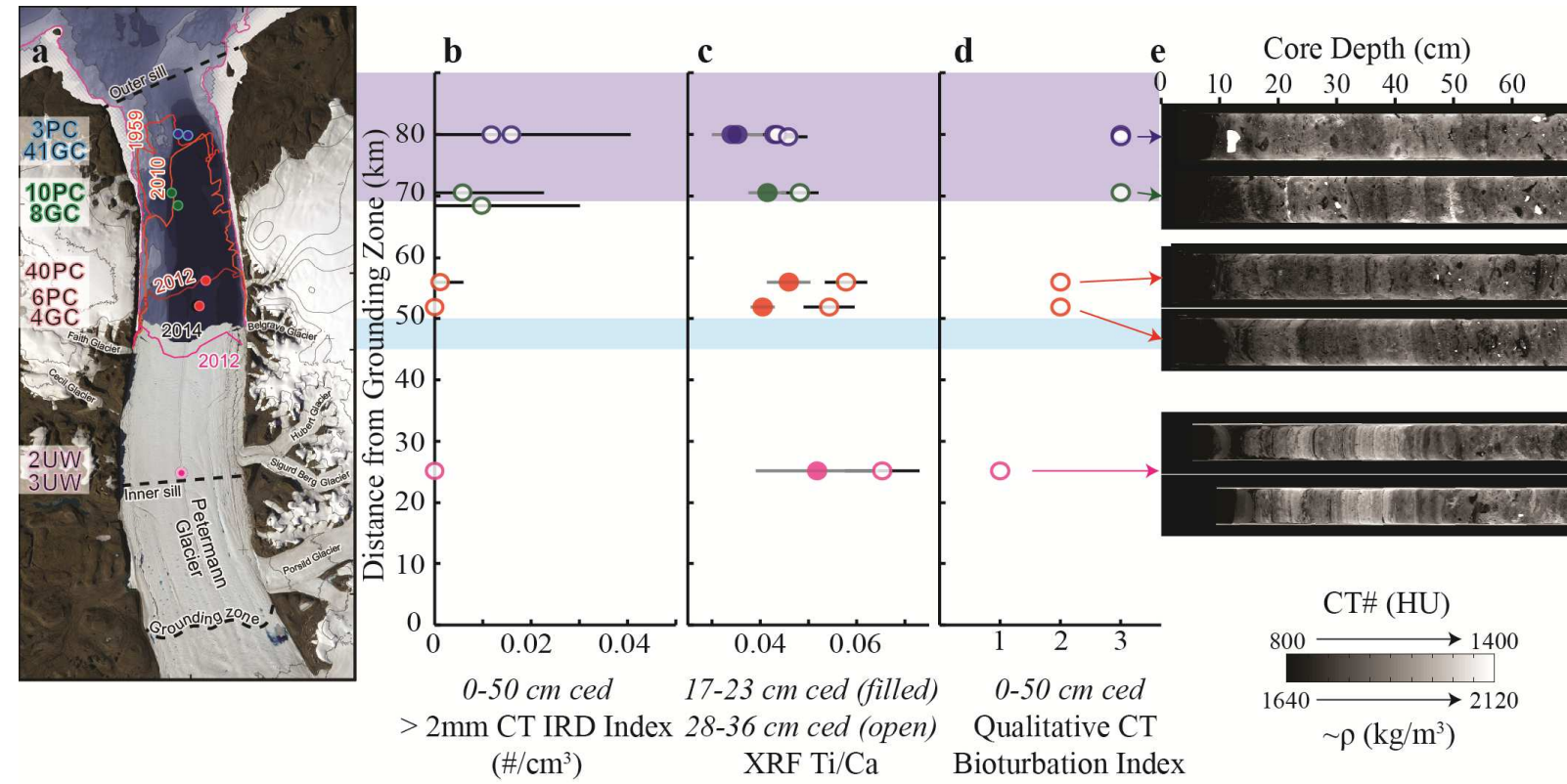

Figure 3. Gradients in near surface sediment properties along Petermann Fjord transect.

(a) Petermann fjord sediment cores and historical ice tongue extents from 1959, before the large calving event in 2010, and before and after the large calving event in 2012. (b) Mean and standard deviation of the $>2 \mathrm{~mm}$ CT IRD Index in the upper $50 \mathrm{~cm}$ of the fjord correlated equivalent depth (ced). (c) Mean and standard deviation of a relative low (17-23 cm ced; filled) and relative high (28-36 cm ced; open) XRF Ti/Ca ratio. (d) Qualitative CT bioturbation index. (e) $2 \mathrm{~mm}$ thick CT slices of the uppermost recovered sediments, from top to bottom, 03TC, 10TC, 40TC, 06TC, 03UW, and 02UW (dark = low density; light = high density; larger versions of the images can be found in Supplemental Figure S3). In b-d, purple shading represents the range of historical ice tongue extents observed between 1879 and 2009. Light blue shading indicates the range observed since the 2012 calving event. 


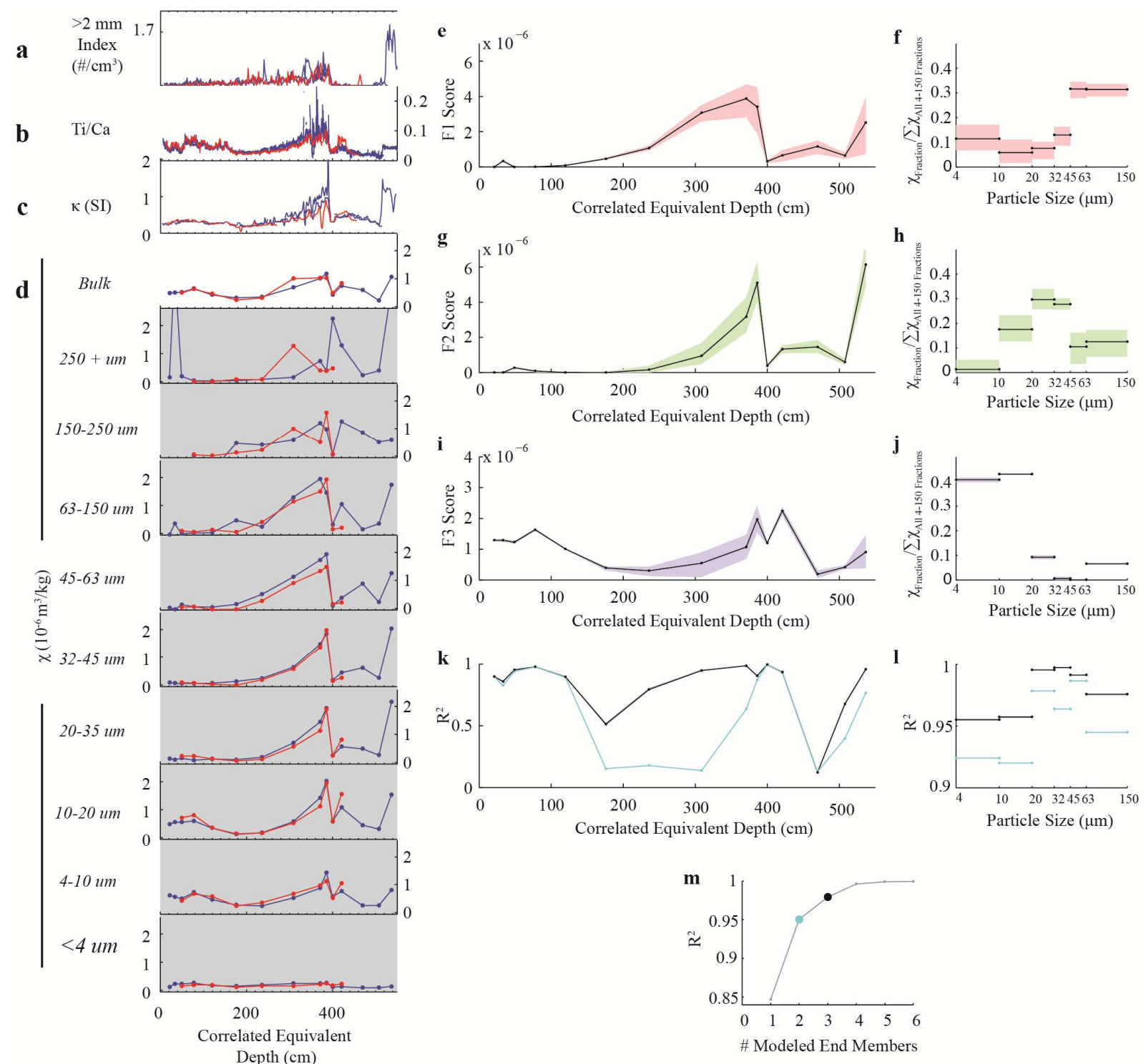

Figure 4. Downcore particle size specific magnetic susceptibility. (a-d), Downcore plots for the outer fjord splice (blue) and 04GC (red) on the correlated equivalent depth scale, including the (a) CT >2 mm index, (b) XRF Ti/Ca ratios, (c) u-channel volume normalized $\kappa$, and (d) subsampled mass normalized $\chi$ for bulk sediment and particle size fractions. (e-j), Endmember modeling results for $\chi$ as a function of particle size in the outer splice cores and 04GC. Shading represents the one sigma range calculated from 1000 iterations with each iteration using a different random initial condition. Factor loadings $(\mathbf{f}, \mathbf{h}, \mathbf{j})$ were normalized by the sum factor loading of all six size fractions to represent the fraction of $\chi$ in the particle size fraction, relative to the sum $\chi$ all 4-150 $\mu \mathrm{m}$ fractions. (k-m) To assess the model, $\mathrm{R}^{2}$ values of the model results and primary data were calculated at core depths $(\mathbf{k})$, for each particle size fraction (l), and for all data using models that used 1-6 end members $(\mathbf{m})$. We choose a three-endmember model (black lines in $\mathbf{k}$ and $\mathbf{l}$; black circle in $\mathbf{m}$ ) over a two- (cyan lines in $\mathbf{k}$ and $\mathbf{l}$; cyan circle in $\mathbf{m}$ ) or fourendmember model, as there is little benefit to including more endmembers and there is a poor model fit from $175-308 \mathrm{~cm}$ ced in the two-endmember model scenario. 


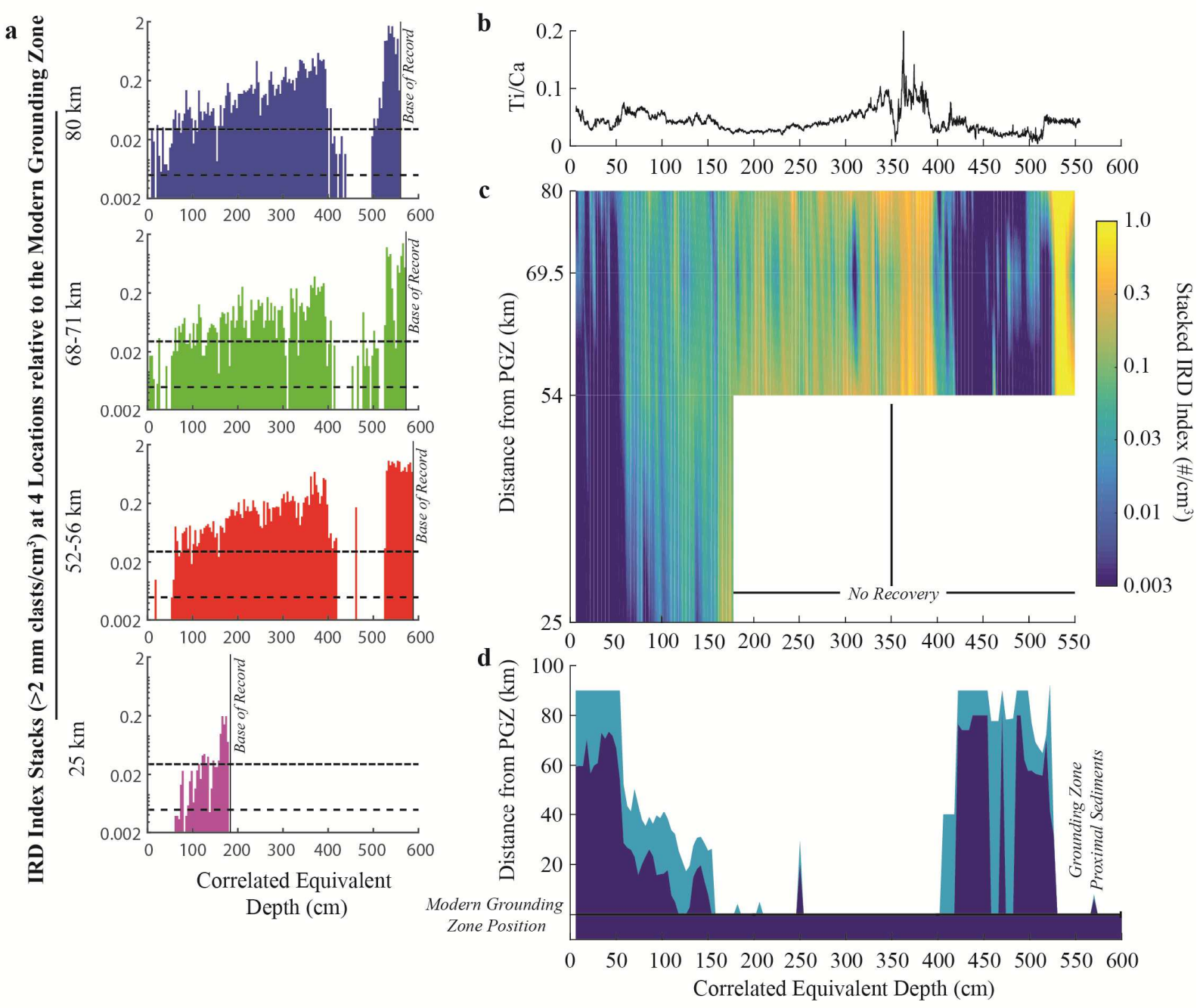

Figure 5. Reconstructing past spatial patterns of IRD deposition in Petermann Fjord. (a)

Stacks of the CT IRD Index at four locations relative to the modern grounding zone position. Dashed lines indicate concentrations of 0.005 and 0.03 clasts $/ \mathrm{cm}^{3}$ used for reconstructing the ice tongue (see text). (b) XRF Ti/Ca ratios that track the relative contribution of Petermann sourced materials to bulk sediment. (c) Heat plot of the down stratigraphy IRD index stacks, interpolated between coring locations. (d) Estimates of past ice tongue extents based on the spatial pattern of IRD deposition, with dark blue indicating the minimum estimate and light blue indicating the maximum estimate. PGZ = Petermann Grounding Zone. 

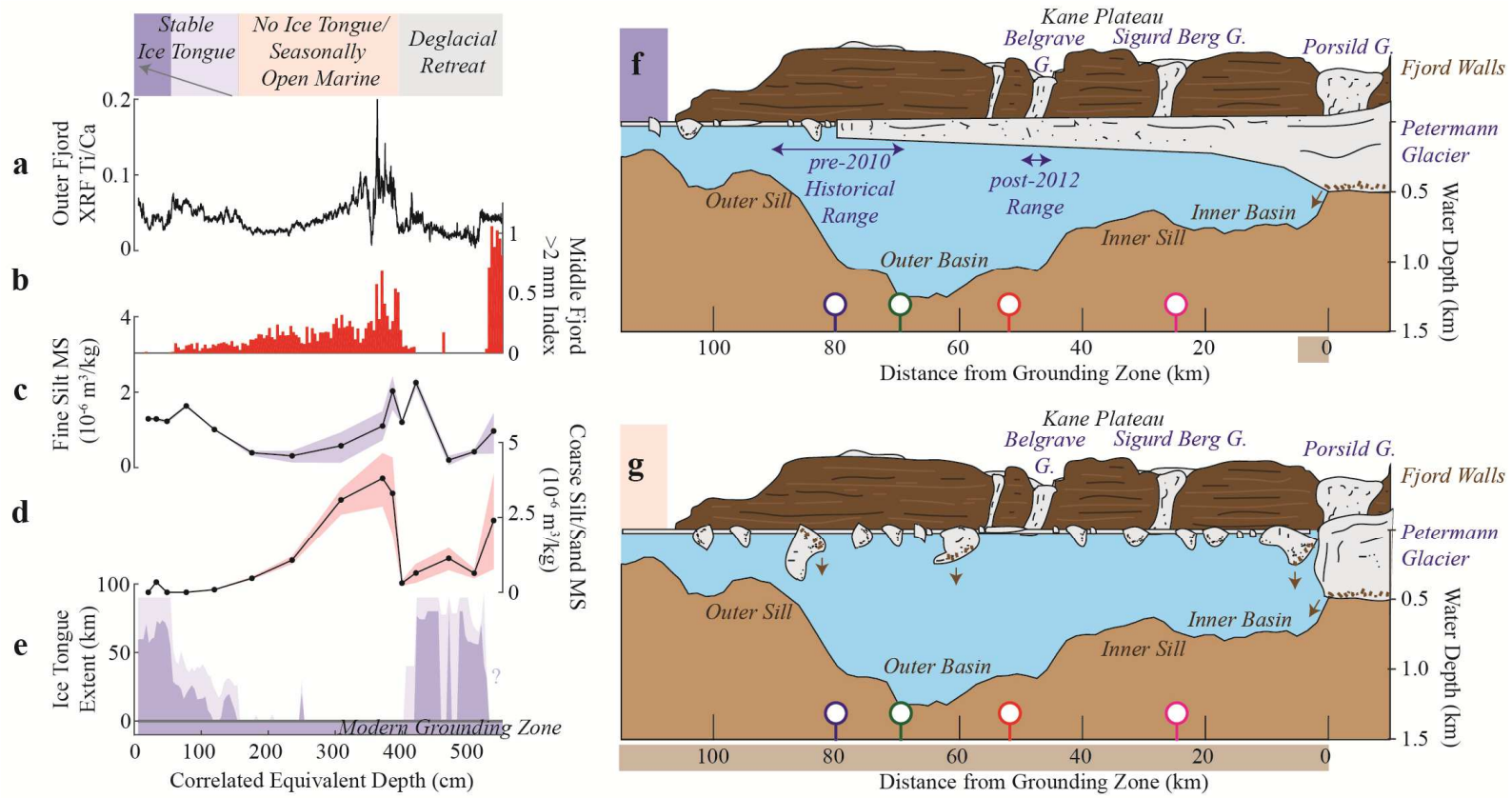

Figure 6. Reconstructing the Petermann Ice Tongue history. Ice tongue reconstruction on depth, documenting glacial retreat and ice tongue break-up, seasonally open marine conditions with no ice tongue in Petermann Fjord, and reestablishment and regrowth of the Petermann Ice Tongue. (a) XRF Ti/Ca in the outer fjord splice trace the relative abundance of Petermann Glacier sourced materials to bulk sediment composition. (b) Peterman Fjord stacked $>2 \mathrm{~mm}$ clast index for fjord cores $52-56 \mathrm{~km}$ from the modern grounding zone. (c) MS of fine silt, calculated from particle size specific measurements of the outer fjord splice and a core $52 \mathrm{~km}$ from the modern grounding zone, tracks the relative contribution of Petermann Glacier sourced material to fine sediments transported in the water column by turbid melt water plumes (Figure 4). (d) MS of coarse silt and sand, as in (c), tracking the relative contribution of Petermann Glacier to IRD following the initial glacial retreat and ice tongue break-up. (e) Multi-decadal to centennial ice tongue extent estimates, relative to modern grounding zone, from the spatial distribution of IRD in the fjord, with darker blue indicating the minimum and light blue indicating the maximum estimated ranges (Figure 6). (f-g), Illustrations of the Petermann Glacier when terminated with a stable ice tongue $70-90 \mathrm{~km}$ long as observed in the pre-2010 historical record and where there was no stable ice tongue and seasonally open marine conditions in the fjord. Bathymetric profile is the gravity modeled east transect of Tinto et al. (2015) and ice tongue draft is after Münchow et al. (2014). Colored pins indicate coring locations used in this study's transect. Small brown arrows indicate sources for high MS Petermann basal ice sourced coarse material, while brown shading along the distance axis indicates the zones in which the same material would be deposited in each scenario. 


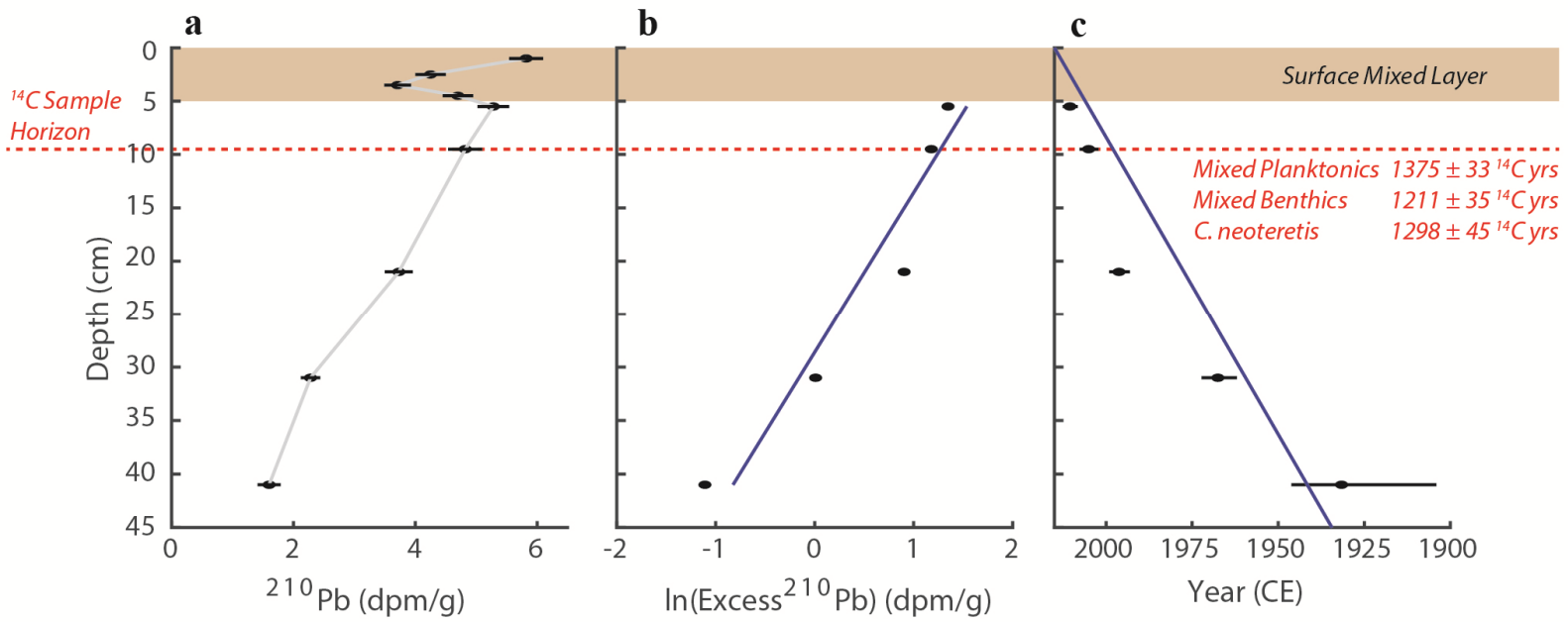

Figure 7. Comparison of ${ }^{210} \mathrm{~Pb}$ and ${ }^{14} \mathrm{C}$ data. Horizon with mixed planktonic foraminifera, mixed benthic foraminifera, and C. neoteretis radiocarbon samples indicated with dashed red line. (a) ${ }^{210} \mathrm{~Pb}$ profile from $38 \mathrm{MC}$ indicates a surface mix layer of $\sim 5 \mathrm{~cm}$ at $38 \mathrm{MC}$ (brown shading). (b) Regression of $\ln \left(\right.$ Excess ${ }^{210} \mathrm{~Pb}$ ) indicates accumulation rates at this site of $300-1000$ $\mathrm{cm} / \mathrm{ka}$ (95\% C.I.). (c) The resulting age-depth relationship suggests available radiocarbon dates are post-bomb (after 1960s) and likely deposited in the last $\sim 10-30$ years. Radiocarbon ages suggest incorporation of very old carbon, but it is difficult to constrain the $\Delta \mathrm{R}$ due to the unknown influence of ${ }^{14} \mathrm{C}$ produced during nuclear bomb testing on dissolved inorganic carbon in Petermann Fjord. 

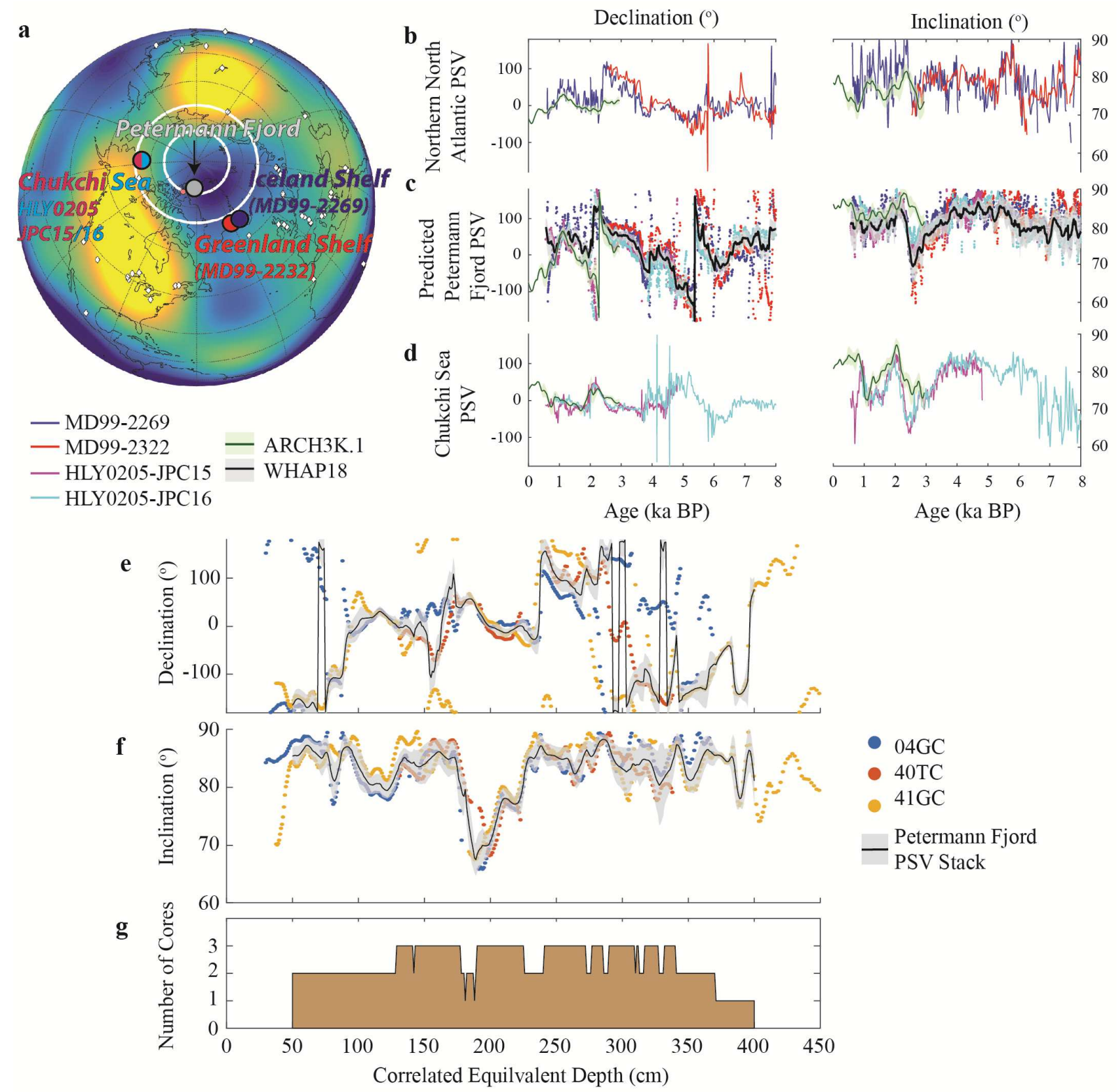

Figure 8. Petermann Fjord predicted and reconstructed PSV. (a) Historical (1590-1990 AD) time average field of the radial magnetic field strength at the core mantle boundary $(2880 \mathrm{~km}$ below Earth's surface) from the GUFM1 field model (Jackson et al., 2000), with yellows indicating high field intensity and blues indicating low or negative field intensities. Locations of high resolution and well dated arctic paleomagnetic records from the Chukchi Sea (Lund et al., 2016) and Northern North Atlantic (Stoner et al., 2013, 2007) used to create the Western Hemisphere Arctic PSV Template (WHAP18) indicated, along with the location of Petermann Fjord. (b-d), Declination and inclination records from the Northern North Atlantic (b) and Chukchi Sea (d) were projected to the location of Petermann Fjord via their virtual geomagnetic pole paths (dots in c). The vector mean (black line in $\mathbf{c}$ ) and standard error (gray shading in $\mathbf{c}$ ) of the projected data are used as the predicted declination and inclination variations at Petermann Fjord. For comparison, site predictions for each location from a higher complexity spherical harmonic model based on archaeomagnetic and volcanic data for the last 3000 years, ARCH3k.1 
1020 (Korte et al., 2009), are included (green line) with one sigma uncertainty (green shading). Data, model, and WHAP18 Petermann Fjord predictions agree best in the overlapping time interval from about 1-2.5 ka, were data coverage for the ARCH3k.1 is best (Donadini et al., 2009). (e-g) PSV stack (black line) and standard error (gray shading) for Petermann Fjord Cores 04GC (blue), 40TC (red), and 41GC (yellow), including (a) declination, (b) inclination, and (c) number of cores contributing to each $5 \mathrm{~cm}$ bin. AF demagnetization results can be found in

1026 Supplementary Figure S7. 

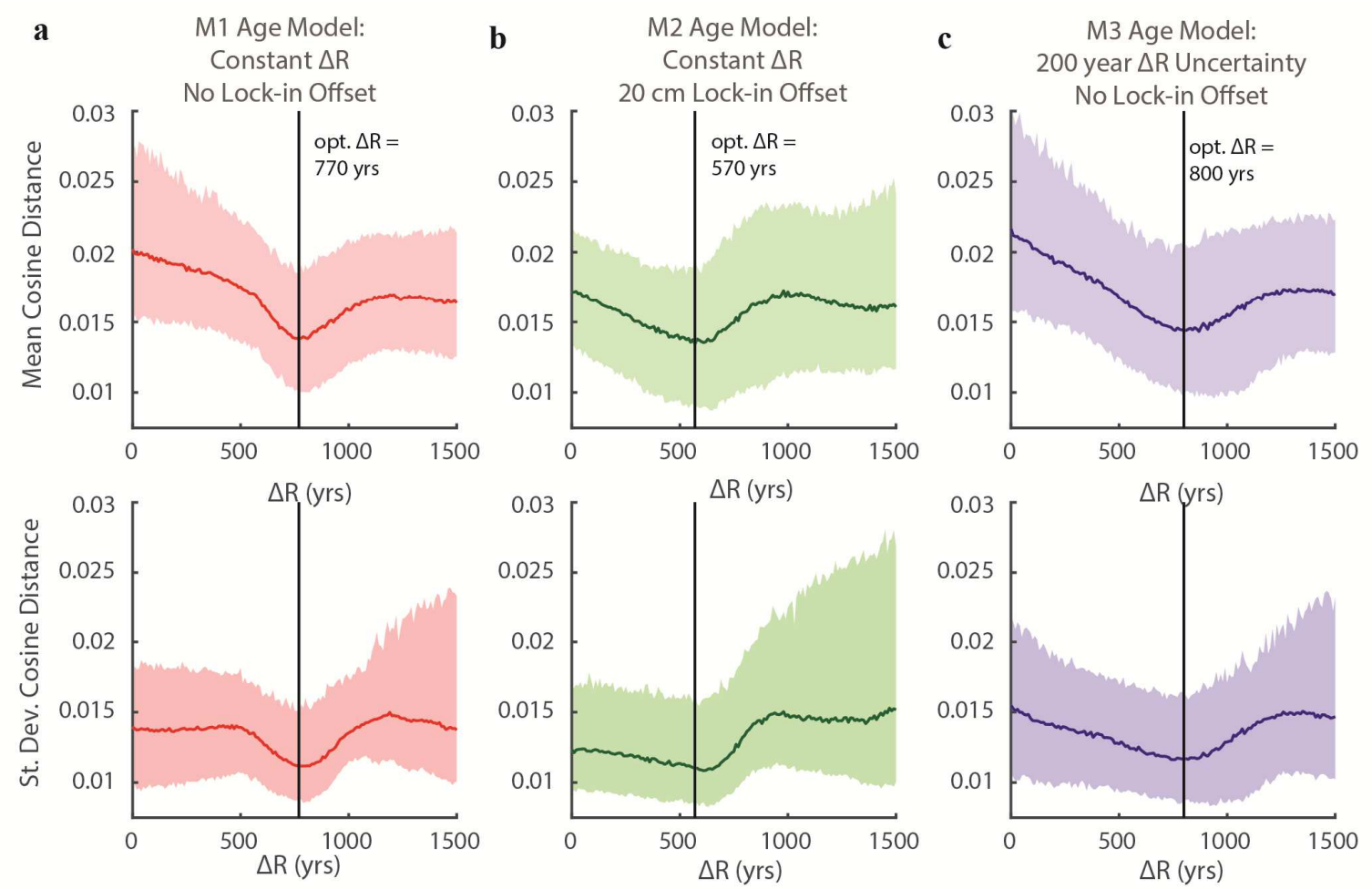

Figure 9. Assessment of apparent radiocarbon age offset in Petermann Fjord with PSV. Sensitivity tests of PSV optimized $\triangle \mathrm{R}$, through comparison of the Petermann PSV stack to the WHAP18 reference template, quantified by calculating the cosine distance where the two records overlap for each of the 1000 age-depth models at each $\Delta \mathrm{R}$ choice. The minimum mean cosine distance for each scenario is used as the optimized $\Delta \mathrm{R}$ (results and implications summarized in Table 2). (a) M1 uses constant $\Delta \mathrm{R}$ and assumes no offset in the depth of the magnetization. (b) M2 is like M1, except we assume a $20 \mathrm{~cm}$ offset in the depth of the magnetization. (c) M3 is like M1, except we assign a 200 year uncertainty to each $\Delta R$. Shading represents the $95 \%$ interval from the 1000 iterations. 
a

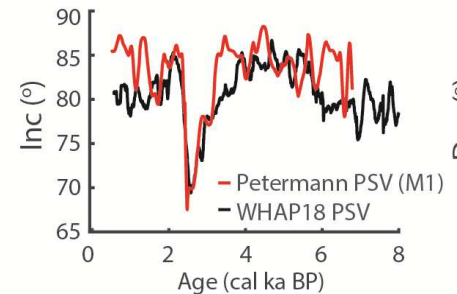

b

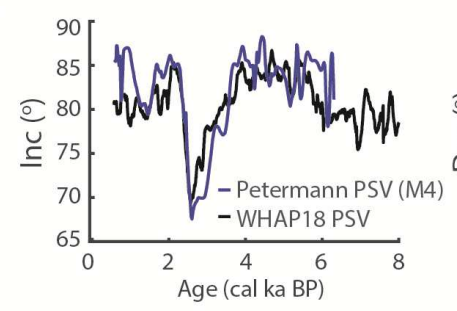

d

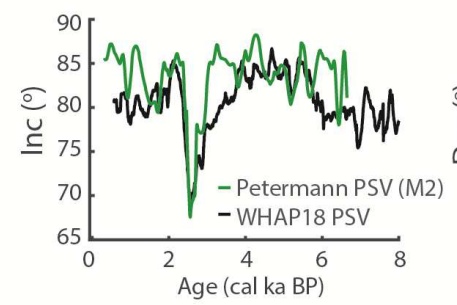

e

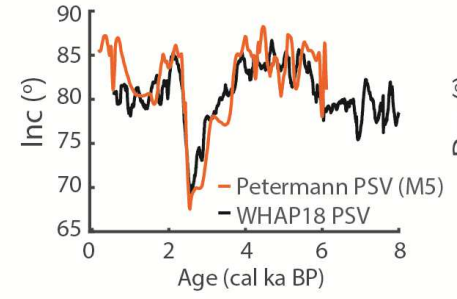

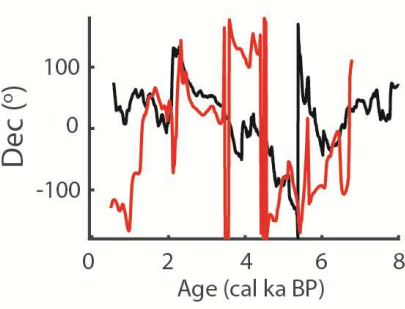
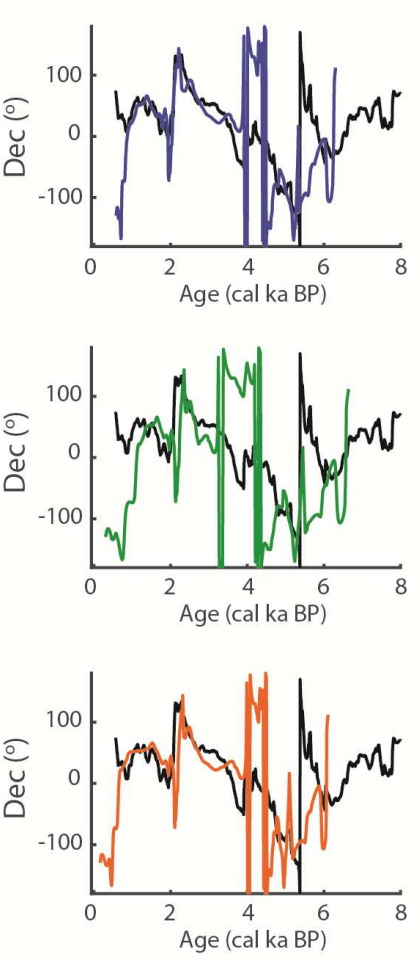

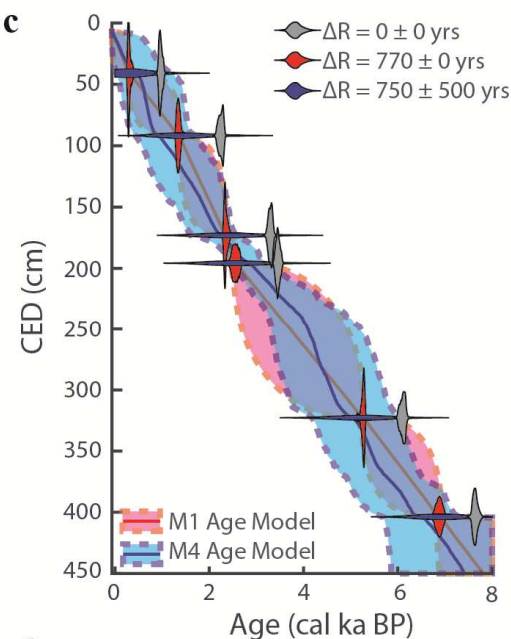

$\mathbf{f}$

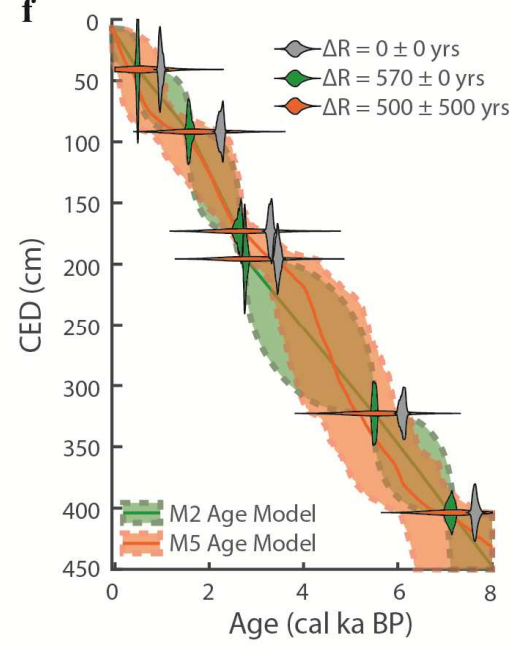

1041
Figure 10. PSV constrained radiocarbon age models. Comparison of possible age models given assumptions of constant versus variable $\Delta R$ and no offset versus $20 \mathrm{~cm}$ offset in magnetization depth (summarized in Table 2). (a-b) Comparison of the Petermann PSV stack with no offset in magnetization depth to the WHAP18 template on the M1 and M4 age model median age, where M1 assumes a constant 770 yr $\Delta \mathrm{R}$ and M4 assumes a variable $\Delta \mathrm{R}$ and only accepts the best $1 \%$ of PSV fits. (c) Comparison of the uncertainty structures for the M1 and M4 age models. (d-e) Comparison of the Petermann PSV stack with a $20 \mathrm{~cm}$ offset in magnetization depth to the WHAP18 template on the M2 and M5 age model median age, where M1 assumes a constant $570 \mathrm{yr} \Delta \mathrm{R}$ and M5 assumes a variable $\Delta \mathrm{R}$ and only accepts the best $1 \%$ of PSV fits. (f) Comparison of the uncertainty structures for the M2 and M5 age models. 


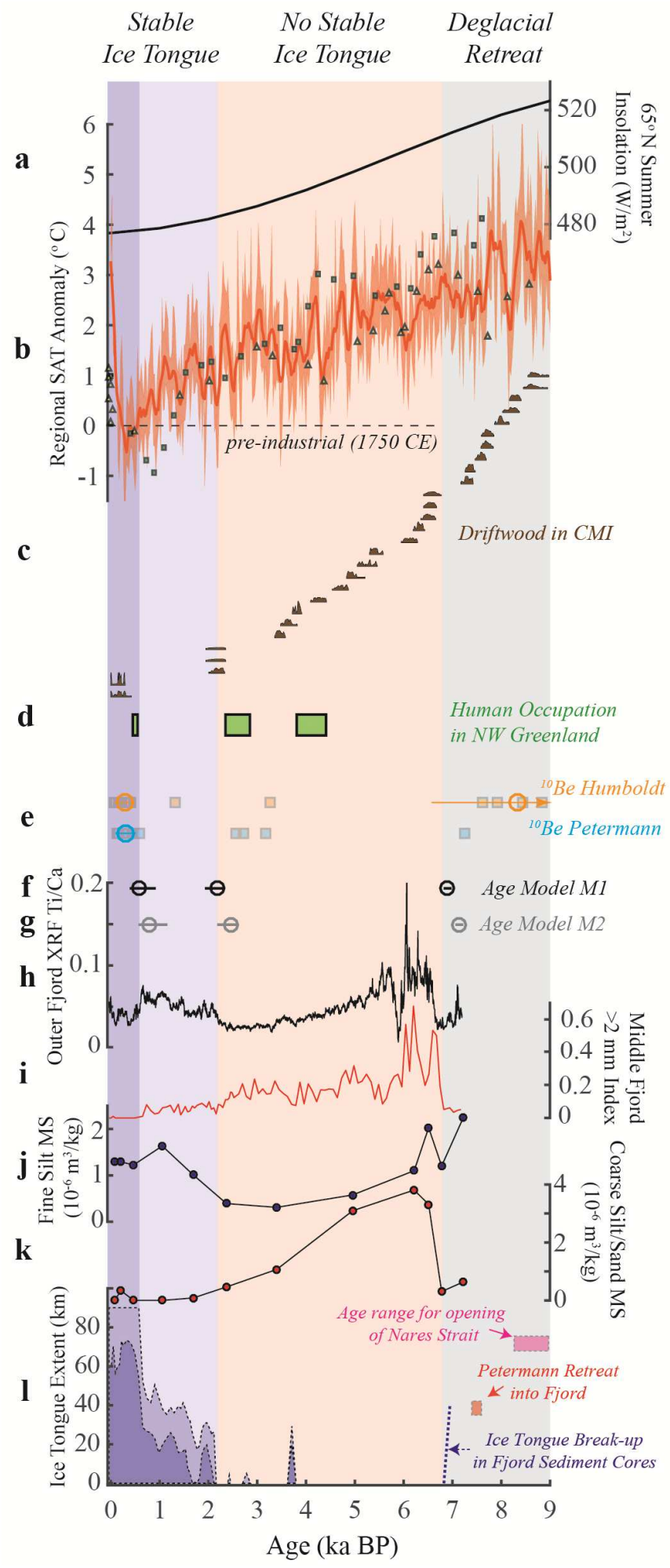

Figure 11. Petermann Ice Tongue history in the context of paleoenvironmental conditions. open marine conditions in the fjord (red), reestablishment of the ice tongue (light blue), and an 
1059

1060

1061

1062

1063

1064

1065

1066

1067

1068

1069

1070

1071

1072

1073

1074

1075

1076

1077

1078

1079

1080

1081

1082

median age of the M1 age model (Figure 10; Table 2). (a) $65^{\circ} \mathrm{N}$ summer insolation, illustrating the long-term Holocene reduction in northern hemisphere insolation by changes in Earth's orbit (Laskar et al., 2004). (b) Regional surface air temperature (SAT) anomaly estimates reconstructed from the Agassiz Ice Core relative to 1750 CE (Lecavalier et al., 2017). Shading represents the $\pm 2 \sigma$ confidence interval and line is the 10 -year running mean. Relative temperature changes reconstructed from Secret Lake (squares; local summer precipitation $\delta^{18} \mathrm{O}$ calibration, Lasher et al., 2017) and Deltas $\varnothing$ (triangles; FOR15 chironomid calibration, Axford et al., 2019) also show a similar cooling trend during the Holocene. (c) Calibrated radiocarbon age distributions for driftwood deposited in the Clements Markham Inlet (CMI), Ellesmere Island, indicating seasonally reduced sea-ice conditions in the Lincoln Sea during the middle Holocene (England et al., 2008). (d) Time intervals with evidence for human settlement in Northern Greenland of the Independence I, Independence II, and Thule cultures (Grønnow and Jensen, 2003). (e) ${ }^{10} \mathrm{Be}$ cosmogenic exposure ages for Humboldt Glacier (orange squares) and Petermann Glacier (blue squares), with interpreted landform ages (circles) and $\pm 1 \sigma$ uncertainty (lines) (Reusche et al., 2018). Note the uncertainty for the $\sim 8.3 \mathrm{ka}$ Humbolt Glacier moraine age extends to ages older than $9 \mathrm{ka}$. (f) Median age (circle) and $\pm 1 \sigma$ uncertainty of the major transitions in Petermann Ice Tongue history using the M1 age model with $\Delta \mathrm{R}$ of $770 \mathrm{yrs}$. (g) Like (f), but using the M2 age model, which is a sensitivity test that explores the uncertainty in the depth the sediment remanent magnetization is acquired (Figures 9-10; Table 2). (h-l) XRF, IRD, particle size specific magnetic susceptibility, and ice tongue reconstruction (as in Figure 6) plotted on the M1 age model. Early Holocene deglacial estimated age ranges for the opening of Nares Strait (after Georgiadis et al., 2018; Jennings et al., 2019, 2011), retreat of the Petermann Glacier from the outer sill into Petermann Fjord (orange; after Jakobsson et al., 2018), and ice tongue break-up documented in the sediment cores discussed in this study (blue dashed line) are indicated. 
1084

1085

1086

1087

1088

1089

1090

1091

1092

1093

1094

1095

1096

1097

1098

1099

1100

1101

1102

1103

1104

1105

1106

1107

1108

1109

1110

1111

1112

1113

1114

1115

1116

1117

1118

1119

1120

1121

1122

1123

1124

1125

1126

1127

Alley, R.B., Andrews, J.T., Barber, D.C., Clark, P.U., 2005. Comment on "Catastrophic ice shelf breakup as the source of Heinrich event icebergs" by C. L. Hulbe et al. Paleoceanography 20, PA1009. https://doi.org/10.1029/2004PA001086

Alley, R.B., Blankenship, D.D., Rooney, S.T., Bentley, C.R., 1989. Sedimentation beneath ice shelves - the view from ice stream B. Mar. Geol. 85, 101-120. https://doi.org/10.1016/0025-3227(89)90150-3

Alley, R.B., Cuffey, K.M., Evenson, E.B., Strasser, J.C., Lawson, D.E., Larson, G.J., 1997. How glaciers entrain and transport basal sediment: Physical constraints. Quat. Sci. Rev. 16, 1017-1038. https://doi.org/10.1016/S0277-3791(97)00034-6

Andrews, J.T., 2000. Icebergs and iceberg rafted detritus (IRD) in the North Atlantic: facts and assumptions. Oceanography 13, 100-108.

Ashley, G.M., Smith, N.D., 2000. Marine sedimentation at a calving glacier margin. Geol. Soc. Am. Bull. 112, 657-667. https://doi.org/10.1130/00167606(2000)112<657:MSAACG >2.0.CO;2

Axford, Y., Lasher, G.E., Kelly, M.A., Osterberg, E.C., Landis, J., Schellinger, G.C., Pfeiffer, A., Thompson, E., Francis, D.R., 2019. Holocene temperature history of northwest Greenland - With new ice cap constraints and chironomid assemblages from Deltas $\emptyset$. Quat. Sci. Rev. 215, 160-172. https://doi.org/10.1016/j.quascirev.2019.05.011

Banerjee, S.K., King, J., Marvin, J., 1981. A rapid method for magnetic granulometry with applications to environmental studies. Geophys. Res. Lett. 8, 333-336. https://doi.org/10.1029/GL008i004p00333

Bartels, M., Titschack, J., Fahl, K., Stein, R., Seidenkrantz, M.-S., Hillaire-Marcel, C., Hebbeln, D., 2017. Atlantic Water advection vs. glacier dynamics in northern Spitsbergen since early deglaciation. Clim Past 13, 1717-1749. https://doi.org/10.5194/cp-13-1717-2017

Bennike, O., 2002. Late Quaternary history of Washington Land, North Greenland. Boreas 31, 260-272. https://doi.org/10.1111/j.1502-3885.2002.tb01072.x

Briner, J.P., Stewart, H.A.M., Young, N.E., Philipps, W., Losee, S., 2010. Using proglacialthreshold lakes to constrain fluctuations of the Jakobshavn Isbræ ice margin, western Greenland, during the Holocene. Quat. Sci. Rev. 29, 3861-3874. https://doi.org/10.1016/j.quascirev.2010.09.005

Buizert, C., Keisling, B.A., Box, J.E., He, F., Carlson, A.E., Sinclair, G., DeConto, R.M., 2018. Greenland-Wide Seasonal Temperatures During the Last Deglaciation. Geophys. Res. Lett. 45, 1905-1914. https://doi.org/10.1002/2017GL075601

Cai, C., Rignot, E., Menemenlis, D., Nakayama, Y., 2017. Observations and modeling of oceaninduced melt beneath Petermann Glacier Ice Shelf in northwestern Greenland. Geophys. Res. Lett. 2017GL073711. https://doi.org/10.1002/2017GL073711

Channell, J.E.T., Guyodo, Y., 2004. The Matuyama Chronozone at ODP Site 982 (Rockall Bank): Evidence for Decimeter-Scale Magnetization Lock-In Depths, in: Channell, J.E.T., Kent, D.V., Lowrie, W., Meert, J.G. (Eds.), Timescales Of The Paleomagnetic Field. American Geophysical Union, pp. 205-219.

Christ, A.J., Talaia-Murray, M., Elking, N., Domack, E.W., Leventer, A., Lavoie, C., Brachfeld, S., Yoo, K.-C., Gilbert, R., Jeong, S.-M., others, 2014. Late Holocene glacial advance and ice shelf growth in Barilari Bay, Graham Land, west Antarctic Peninsula. Geol. Soc. Am. Bull. 127, 297-315. 
1128

1129

1130

1131

1132

1133

1134

1135

1136

1137

1138

1139

1140

1141

1142

1143

1144

1145

1146

1147

1148

1149

1150

1151

1152

1153

1154

1155

1156

1157

1158

1159

1160

1161

1162

1163

1164

1165

1166

1167

1168

1169

1170

1171

Clark, P.U., Shakun, J.D., Marcott, S.A., Mix, A.C., Eby, M., Kulp, S., Levermann, A., Milne, G.A., Pfister, P.L., Santer, B.D., Schrag, D.P., Solomon, S., Stocker, T.F., Strauss, B.H., Weaver, A.J., Winkelmann, R., Archer, D., Bard, E., Goldner, A., Lambeck, K., Pierrehumbert, R.T., Plattner, G.-K., 2016. Consequences of twenty-first-century policy for multi-millennial climate and sea-level change. Nat. Clim. Change 6, 360-369. https://doi.org/10.1038/nclimate2923

Coulthard, R.D., Furze, M.F.A., Pieńkowski, A.J., Chantel Nixon, F., England, J.H., 2010. New marine $\Delta \mathrm{R}$ values for Arctic Canada. Quat. Geochronol. 5, 419-434. https://doi.org/10.1016/j.quageo.2010.03.002

Cowan, E.A., Powell, R.D., 1990. Suspended sediment transport and deposition of cyclically interlaminated sediment in a temperate glacial fjord, Alaska, USA. Geol. Soc. Lond. Spec. Publ. 53, 75-89.

Darby, D.A., Ortiz, J.D., Grosch, C.E., Lund, S.P., 2012. 1,500-year cycle in the Arctic Oscillation identified in Holocene Arctic sea-ice drift. Nat. Geosci. 5, 897-900. https://doi.org/10.1038/ngeo1629

Dawes, P.R., Frisch, T., Garde, A.A., Iannelli, T.R., Ineson, J.R., Jensen, S.M., Pirajno, F., Sønderholm, M., Stemmerik, L., Stouge, S., others, 2000a. Kane Basin 1999: mapping, stratigraphic studies and economic assessment of Precambrian and Lower Palaeozoic provinces in north-western Greenland. Geol. Greenl. Surv. Bull. 186, 11-28.

Dawes, P.R., Thomassen, B., Andersson, T.H., Ice, I., 2000b. A new volcanic province: evidence from glacial erratics in western North Greenland. Geol. Greenl. Surv. Bull. 186, 35-41.

Domack, E.W., 1990. Laminated terrigenous sediments from the Antarctic Peninsula: the role of subglacial and marine processes, in: Glacimarine Environments: Processes and Sediments, Geological Society Special Publication. pp. 91-103.

Domack, E.W., Harris, P.T., 1998. A new depositional model for ice shelves, based upon sediment cores from the Ross Sea and the Mac. Robertson shelf, Antarctica. Ann. Glaciol. 27, 281-284.

Domack, E.W., Ishman, S., 1993. Oceanographic and physiographic controls on modern sedimentation within Antarctic fjords. Geol. Soc. Am. Bull. 105, 1175-1189. https://doi.org/10.1130/0016-7606

Donadini, F., Korte, M., Constable, C.G., 2009. Geomagnetic field for 0-3 ka: 1. New data sets for global modeling. Geochem. Geophys. Geosystems 10, Q06007. https://doi.org/10.1029/2008GC002295

Dowdeswell, J.A., Dowdeswell, E.K., 1989. Debris in Icebergs and Rates of Glaci-Marine Sedimentation: Observations from Spitsbergen and a Simple Model. J. Geol. 97, 221231.

Dunhill, G., Andrews, J.T., Kristjánsdóttir, G., 2004. Radiocarbon Date List X: Baffin Bay, Baffin Island, Iceland, Labrador Sea, and the Northern North Atlantic (No. 56), Occasional Paper. Institute of Arctic and Alpine Research, University of Colorado, Boulder.

Egli, R., 2013. VARIFORC: An optimized protocol for calculating non-regular first-order reversal curve (FORC) diagrams. Glob. Planet. Change, Magnetic iron minerals in sediments and their relation to geologic processes, climate, and the geomagnetic field 110, 302-320. https://doi.org/10.1016/j.gloplacha.2013.08.003 
1172

1173

1174

1175

1176

1177

1178

1179

1180

1181

1182

1183

1184

1185

1186

1187

1188

1189

1190

1191

1192

1193

1194

1195

1196

1197

1198

1199

1200

1201

1202

1203

1204

1205

1206

1207

1208

1209

1210

1211

1212

1213

1214

1215

1216

Egli, R., Zhao, X., 2015. Natural remanent magnetization acquisition in bioturbated sediment: General theory and implications for relative paleointensity reconstructions. Geochem. Geophys. Geosystems 16, 995-1016. https://doi.org/10.1002/2014GC005672

England, J., 1999. Coalescent Greenland and Innuitian ice during the Last Glacial Maximum: revising the Quaternary of the Canadian High Arctic. Quat. Sci. Rev. 18, 421-456. https://doi.org/10.1016/S0277-3791(98)00070-5

England, J.H., Lakeman, T.R., Lemmen, D.S., Bednarski, J.M., Stewart, T.G., Evans, D.J.A., 2008. A millennial-scale record of Arctic Ocean sea ice variability and the demise of the Ellesmere Island ice shelves. Geophys. Res. Lett. 35, L19502. https://doi.org/10.1029/2008GL034470

Evans, J., Pudsey, C.J., 2002. Sedimentation associated with Antarctic Peninsula ice shelves: implications for palaeoenvironmental reconstructions of glacimarine sediments. J. Geol. Soc. 159, 233-237. https://doi.org/10.1144/0016-764901-125

Falkner, K.K., Melling, H., Mnchow, A.M., Box, J.E., Wohlleben, T., Johnson, H.L., Gudmandsen, P., Samelson, R., Copland, L., Steffen, K., others, 2011. Context for the recent massive Petermann Glacier calving event. Eos 92.

Fallon, S.J., Fifield, L.K., Chappell, J.M., 2010. The next chapter in radiocarbon dating at the Australian National University: Status report on the single stage AMS. Nucl. Instrum. Methods Phys. Res. Sect. B Beam Interact. Mater. At., Proceedings of the Eleventh International Conference on Accelerator Mass Spectrometry 268, 898-901. https://doi.org/10.1016/j.nimb.2009.10.059

Farnsworth, L.B., Kelly, M.A., Bromley, G.R.M., Axford, Y., Osterberg, E.C., Howley, J.A., Jackson, M.S., Zimmerman, S.R., 2018. Holocene history of the Greenland Ice-Sheet margin in Northern Nunatarssuaq, Northwest Greenland. arktos 4, 10. https://doi.org/10.1007/s41063-018-0044-0

Fettweis, X., Franco, B., Tedesco, M., van Angelen, J.H., Lenaerts, J.T.M., van den Broeke, M.R., Gallée, H., 2013. Estimating the Greenland ice sheet surface mass balance contribution to future sea level rise using the regional atmospheric climate model MAR. The Cryosphere 7, 469-489. https://doi.org/10.5194/tc-7-469-2013

Fisher, R., 1953. Dispersion on a Sphere. Proc. Natl. Acad. Sci. U. S. Am. Math. Phys. Sci. 217 , 295-305.

Fortin, D., Francus, P., Gebhardt, A.C., Hahn, A., Kliem, P., Lisé-Pronovost, A., Roychowdhury, R., Labrie, J., St-Onge, G., 2013. Destructive and non-destructive density determination: method comparison and evaluation from the Laguna Potrok Aike sedimentary record. Quat. Sci. Rev. 71, 147-153. https://doi.org/10.1016/j.quascirev.2012.08.024

Funder, S., Goosse, H., Jepsen, H., Kaas, E., Kjaer, K.H., Korsgaard, N.J., Larsen, N.K., Linderson, H., Lysa, A., Moller, P., Olsen, J., Willerslev, E., 2011. A 10,000-Year Record of Arctic Ocean Sea-Ice Variability--View from the Beach. Science 333, 747750. https://doi.org/10.1126/science. 1202760

Genevey, A., Gallet, Y., Constable, C.G., Korte, M., Hulot, G., 2008. ArcheoInt: An upgraded compilation of geomagnetic field intensity data for the past ten millennia and its application to the recovery of the past dipole moment. Geochem. Geophys. Geosystems 9, Q04038. https://doi.org/10.1029/2007GC001881

Georgiadis, E., Giraudeau, J., Martinez, P., Lajeunesse, P., St-Onge, G., Schmidt, S., Massé, G., 2018. Deglacial to postglacial history of Nares Strait, Northwest Greenland: a marine 
perspective from Kane Basin. Clim. Past 14, 1991-2010. https://doi.org/10.5194/cp-141991-2018

Grønnow, B., Jensen, J.F., 2003. The Northernmost Ruins of the Globe: Eigil Knuth's Archaeological Investigations in Peary Land and Adjacent Areas of High Arctic Greenland, Monographs on Greenland: Man \& Society. Museum Tusculanum Press, Copenhagen.

Hagstrum, J.T., Champion, D.E., 2002. A Holocene paleosecular variation record from 14Cdated volcanic rocks in western North America. J. Geophys. Res. 107. https://doi.org/10.1029/2001JB000524

Harrison, R.J., Feinberg, J.M., 2008. FORCinel: An improved algorithm for calculating firstorder reversal curve distributions using locally weighted regression smoothing. Geochem. Geophys. Geosystems 9, Q05016. https://doi.org/10.1029/2008GC001987

Harrison, R.J., Muraszko, J., Heslop, D., Lascu, I., Muxworthy, A.R., Roberts, A.P., 2018. An Improved Algorithm For Unmixing First $\square$ Order Reversal Curve Diagrams Using Principal Component Analysis. Geochem. Geophys. Geosystems. https://doi.org/10.1029/2018GC007511

Haslett, J., Parnell, A., 2008. A simple monotone process with application to radiocarbon-dated depth chronologies. J. R. Stat. Soc. Ser. C Appl. Stat. 57, 399-418. https://doi.org/10.1111/j.1467-9876.2008.00623.x

Hatfield, R., 2014. Particle size-specific magnetic measurements as a tool for enhancing our understanding of the bulk magnetic properties of sediments. Minerals 4, 758-787. https://doi.org/10.3390/min4040758

Hatfield, R.G., Stoner, J.S., Reilly, B.T., Tepley, F.J., Wheeler, B.H., Housen, B.A., 2017. Grain size dependent magnetic discrimination of Iceland and South Greenland terrestrial sediments in the northern North Atlantic sediment record. Earth Planet. Sci. Lett. 474, 474-489. https://doi.org/10.1016/j.epsl.2017.06.042

Heslop, D., Dillon, M., 2007. Unmixing magnetic remanence curves without a priori knowledge. Geophys. J. Int. 170, 556-566. https://doi.org/10.1111/j.1365-246X.2007.03432.x

Heuzé, C., Wåhlin, A., Johnson, H.L., Münchow, A., 2016. Pathways of Meltwater Export from Petermann Glacier, Greenland. J. Phys. Oceanogr. 47, 405-418. https://doi.org/10.1175/JPO-D-16-0161.1

Hill, E.A., Gudmundsson, G.H., Carr, J.R., Stokes, C.R., 2018. Velocity response of Petermann Glacier, northwest Greenland, to past and future calving events. The Cryosphere 12, 3907-3921. https://doi.org/10.5194/tc-12-3907-2018

Hodell, D.A., Nicholl, J.A., Bontognali, T.R.R., Danino, S., Dorador, J., Dowdeswell, J.A., Einsle, J., Kuhlmann, H., Martrat, B., Mleneck-Vautravers, M.J., Rodríguez-Tovar, F.J., Röhl, U., 2017. Anatomy of Heinrich Layer 1 and its role in the last deglaciation. Paleoceanography 32, 2016PA003028. https://doi.org/10.1002/2016PA003028

Hogg, A.E., Shepherd, A., Gourmelen, N., Engdahl, M., 2016. Grounding line migration from 1992 to 2011 on Petermann Glacier, North-West Greenland. J. Glaciol. 62, 1104-1114. https://doi.org/10.1017/jog.2016.83

Hounsfield, G.N., 1973. Computerized transverse axial scanning (tomography): Part 1. Description of system. Br. J. Radiol. 46, 1016-1022. https://doi.org/10.1259/0007-128546-552-1016 
1261

1262

1263

1264

1265

1266

1267

1268

1269

1270

1271

1272

1273

1274

1275

1276

1277

1278

1279

1280

1281

1282

1283

1284

1285

1286

1287

1288

1289

1290

1291

1292

1293

1294

1295

1296

1297

1298

1299

1300

1301

1302

1303

1304

1305
Irving, E., Major, A., 1964. Post-Depositional Detrital Remanent Magnetization in a Synthetic Sediment. Sedimentology 3, 135-143. https://doi.org/10.1111/j.13653091.1964.tb00638.x

Jackson, A., Jonkers, A.R., Walker, M.R., 2000. Four centuries of geomagnetic secular variation from historical records. Philos. Trans. R. Soc. Lond. Math. Phys. Eng. Sci. 358, 957-990.

Jaeger, J.M., Koppes, M.N., 2016. The role of the cryosphere in source-to-sink systems. EarthSci. Rev., Source-to-Sink Systems: Sediment \& Solute Transfer on the Earth Surface 153, 43-76. https://doi.org/10.1016/j.earscirev.2015.09.011

Jakobsson, M., Hogan, K.A., Mayer, L.A., Mix, A., Jennings, A., Stoner, J., Eriksson, B., Jerram, K., Mohammad, R., Pearce, C., Reilly, B., Stranne, C., 2018. The Holocene retreat dynamics and stability of Petermann Glacier in northwest Greenland. Nat. Commun. 9, 2104. https://doi.org/10.1038/s41467-018-04573-2

Jakobsson, M., Mayer, L., Coakley, B., Dowdeswell, J.A., Forbes, S., Fridman, B., Hodnesdal, H., Noormets, R., Pedersen, R., Rebesco, M., 2012. The international bathymetric chart of the Arctic Ocean (IBCAO) version 3.0. Geophys. Res. Lett. 39.

Jennings, A.E., Andrews, J.T., Oliver, B., Walczak, M., Mix, A., 2019. Retreat of the Smith Sound Ice Stream in the Early Holocene. Boreas 0. https://doi.org/10.1111/bor.12391

Jennings, A.E., Sheldon, C., Cronin, T.M., Francus, P., Stoner, J., Andrews, J., 2011. The Holocene history of Nares Strait: Transition from glacial bay to Arctic-Atlantic throughflow. Oceanography 24, 18-33.

Johnson, H.L., Münchow, A., Falkner, K.K., Melling, H., 2011. Ocean circulation and properties in Petermann Fjord, Greenland. J. Geophys. Res. 116. https://doi.org/10.1029/2010JC006519

Joughin, I., Smith, B.E., Shean, D.E., Floricioiu, D., 2014. Brief Communication: Further summer speedup of Jakobshavn Isbræ. The Cryosphere 8, 209-214. https://doi.org/10.5194/tc-8-209-2014

Kaufman, D.S., Schneider, D.P., McKay, N.P., Ammann, C.M., Bradley, R.S., Briffa, K.R., Miller, G.H., Otto-Bliesner, B.L., Overpeck, J.T., Vinther, B.M., Members, A.L. 2k P., 2009. Recent Warming Reverses Long-Term Arctic Cooling. Science 325, 1236-1239. https://doi.org/10.1126/science.1173983

Keigwin, L.D., Donnelly, J.P., Cook, M.S., Driscoll, N.W., Brigham-Grette, J., 2006. Rapid sealevel rise and Holocene climate in the Chukchi Sea. Geology 34, 861. https://doi.org/10.1130/G22712.1

King, J., Banerjee, S.K., Marvin, J., Özdemir, Ö., 1982. A comparison of different magnetic methods for determining the relative grain size of magnetite in natural materials: Some results from lake sediments. Earth Planet. Sci. Lett. 59, 404-419. https://doi.org/10.1016/0012-821X(82)90142-X

Kirschvink, J.L., 1980. The least-squares line and plane and the analysis of palaeomagnetic data. Geophys. J. R. Astron. Soc. 62, 699-718.

Korte, M., Brown, M.C., Gunnarson, S.R., Nilsson, A., Panovska, S., Wardinski, I., Constable, C.G., 2018. Refining Holocene geochronologies using palaeomagnetic records. Quat. Geochronol. https://doi.org/10.1016/j.quageo.2018.11.004

Korte, M., Donadini, F., Constable, C.G., 2009. Geomagnetic field for 0-3 ka: 2. A new series of time-varying global models. Geochem. Geophys. Geosystems 10, Q06008. https://doi.org/10.1029/2008GC002297 
1306

1307

1308

1309

1310

1311

1312

1313

1314

1315

1316

1317

1318

1319

1320

1321

1322

1323

1324

1325

1326

1327

1328

1329

1330

1331

1332

1333

1334

1335

1336

1337

1338

1339

1340

1341

1342

1343

1344

1345

1346

1347

1348

1349

1350

Kristjánsdóttir, G.B., Stoner, J.S., Jennings, A.E., Andrews, J.T., Grönvold, K., 2007. Geochemistry of Holocene cryptotephras from the North Iceland Shelf (MD99-2269): intercalibration with radiocarbon and palaeomagnetic chronostratigraphies. The Holocene 17, 155-176. https://doi.org/10.1177/0959683607075829

Lasher, G.E., Axford, Y., McFarlin, J.M., Kelly, M.A., Osterberg, E.C., Berkelhammer, M.B., 2017. Holocene temperatures and isotopes of precipitation in Northwest Greenland recorded in lacustrine organic materials. Quat. Sci. Rev. 170, 45-55. https://doi.org/10.1016/j.quascirev.2017.06.016

Laskar, J., Robutel, P., Joutel, F., Gastineau, M., Correia, A.C.M., Levrard, B., 2004. A longterm numerical solution for the insolation quantities of the Earth. Astron. Astrophys. 428, 261-285. https://doi.org/10.1051/0004-6361:20041335

Lecavalier, B.S., Fisher, D.A., Milne, G.A., Vinther, B.M., Tarasov, L., Huybrechts, P., Lacelle, D., Main, B., Zheng, J., Bourgeois, J., Dyke, A.S., 2017. High Arctic Holocene temperature record from the Agassiz ice cap and Greenland ice sheet evolution. Proc. Natl. Acad. Sci. 114, 5952-5957. https://doi.org/10.1073/pnas.1616287114

Lees, J.A., 1997. Mineral magnetic properties of mixtures of environmental and synthetic materials: linear additivity and interaction effects. Geophys. J. Int. 131, 335-346. https://doi.org/10.1111/j.1365-246X.1997.tb01226.x

Lougheed, B., Obrochta, S., 2016. MatCal: Open Source Bayesian ${ }^{14} \mathrm{C}$ Age Calibration in Matlab. J. Open Res. Softw. 4. https://doi.org/10.5334/jors.130

Løvlie, R., 1976. The intensity pattern of post-depositional remanence acquired in some marine sediments deposited during a reversal of the external magnetic field. Earth Planet. Sci. Lett. 30, 209-214. https://doi.org/10.1016/0012-821X(76)90247-8

Lund, S., Keigwin, L., Darby, D., 2016. Character of Holocene Paleomagnetic Secular Variation in the Tangent Cylinder: Evidence from the Chukchi Sea. Phys. Earth Planet. Inter. https://doi.org/10.1016/j.pepi.2016.03.005

Makinson, K., Anker, P.G., 2014. The BAS ice-shelf hot-water drill: design, methods and tools. Ann. Glaciol. 55, 44-52.

Marcott, S.A., Shakun, J.D., Clark, P.U., Mix, A.C., 2013. A Reconstruction of Regional and Global Temperature for the Past 11,300 Years. Science 339, 1198-1201. https://doi.org/10.1126/science.1228026

McFarlin, J.M., Axford, Y., Osburn, M.R., Kelly, M.A., Osterberg, E.C., Farnsworth, L.B., 2018. Pronounced summer warming in northwest Greenland during the Holocene and Last Interglacial. Proc. Natl. Acad. Sci. 201720420. https://doi.org/10.1073/pnas.1720420115

Morlighem, M., Williams, C.N., Rignot, E., An, L., Arndt, J.E., Bamber, J.L., Catania, G., Chauché, N., Dowdeswell, J.A., Dorschel, B., Fenty, I., Hogan, K., Howat, I., Hubbard, A., Jakobsson, M., Jordan, T.M., Kjeldsen, K.K., Millan, R., Mayer, L., Mouginot, J., Noël, B.P.Y., O’Cofaigh, C., Palmer, S., Rysgaard, S., Seroussi, H., Siegert, M.J., Slabon, P., Straneo, F., van den Broeke, M.R., Weinrebe, W., Wood, M., Zinglersen, K.B., 2017. BedMachine v3: Complete Bed Topography and Ocean Bathymetry Mapping of Greenland From Multibeam Echo Sounding Combined With Mass Conservation. Geophys. Res. Lett. 44, 11,051-11,061. https://doi.org/10.1002/2017GL074954

Mouginot, J., Rignot, E., Scheuchl, B., Fenty, I., Khazendar, A., Morlighem, M., Buzzi, A., Paden, J., 2015. Fast retreat of Zachariæ Isstrøm, northeast Greenland. Science 350, 1357-1361. https://doi.org/10.1126/science.aac7111 
1351

1352

1353

1354

1355

1356

1357

1358

1359

1360

1361

1362

1363

1364

1365

1366

1367

1368

1369

1370

1371

1372

1373

1374

1375

1376

1377

1378

1379

1380

1381

1382

1383

1384

1385

1386

1387

1388

1389

1390

1391

1392

1393

1394

1395

Münchow, A., Falkner, K.K., Melling, H., Rabe, B., Johnson, H.L., 2011. Ocean Warming of Nares Strait Bottom Waters off Northwest Greenland, 2003-2009. Oceanography 24, 114.

Münchow, A., Padman, L., Fricker, H.A., 2014. Interannual changes of the floating ice shelf of Petermann Gletscher, North Greenland, from 2000 to 2012. J. Glaciol. 60, 489-499. https://doi.org/10.3189/2014JoG13J135

Münchow, A., Padman, L., Washam, P., Nicholls, K.W., 2016. The Ice Shelf of Petermann Gletscher, North Greenland, and Its Connection to the Arctic and Atlantic Oceans. Oceanography 29, 84-95. https://doi.org/doi.org/10.5670/oceanog.2016.101

Nares, G.S., 1878. Narative of a voyage to the polar sea during 1875-6 in H.M. ships "Alert" and "Discovery." Sampson Low, Marston, Searle, \& Rivington, London.

Nick, F.M., Luckman, A., Vieli, A., Van Der Veen, C.J., Van As, D., Van De Wal, R.S.W., Pattyn, F., Hubbard, A.L., Floricioiu, D., 2012. The response of Petermann Glacier, Greenland, to large calving events, and its future stability in the context of atmospheric and oceanic warming. J. Glaciol. 58, 229-239. https://doi.org/10.3189/2012JoG11J242

Nick, F.M., Vieli, A., Andersen, M.L., Joughin, I., Payne, A., Edwards, T.L., Pattyn, F., van de Wal, R.S.W., 2013. Future sea-level rise from Greenland's main outlet glaciers in a warming climate. Nature 497, 235-238. https://doi.org/10.1038/nature12068

Nilsson, A., Snowball, I., Muscheler, R., Uvo, C.B., 2010. Holocene geocentric dipole tilt model constrained by sedimentary paleomagnetic data. Geochem. Geophys. Geosystems 11. https://doi.org/10.1029/2010GC003118

Ó Cofaigh, C., Dowdeswell, J.A., 2001. Laminated sediments in glacimarine environments: diagnostic criteria for their interpretation. Quat. Sci. Rev. 20, 1411-1436.

Oda, H., Xuan, C., 2014. Deconvolution of continuous paleomagnetic data from pass-through magnetometer: A new algorithm to restore geomagnetic and environmental information based on realistic optimization. Geochem. Geophys. Geosystems 15, 3907-3924. https://doi.org/10.1002/2014GC005513

Ólafsdóttir, S., Reilly, B.T., Bakke, J., Stoner, J.S., Gjerde, M., van der Bilt, W.G.M., 2019. Holocene paleomagnetic secular variation (PSV) near $80^{\circ} \mathrm{N}$, Northwest Spitsbergen, Svalbard: Implications for evaluating High Arctic sediment chronologies. Quat. Sci. Rev. 210, 90-102. https://doi.org/10.1016/j.quascirev.2019.03.003

Orsi, A.J., Kawamura, K., Masson-Delmotte, V., Fettweis, X., Box, J.E., Dahl-Jensen, D., Clow, G.D., Landais, A., Severinghaus, J.P., 2017. The recent warming trend in North Greenland. Geophys. Res. Lett. 2016GL072212. https://doi.org/10.1002/2016GL072212

Reilly, B.T., Natter, C.J., Brachfeld, S.A., 2016. Holocene glacial activity in Barilari Bay, west Antarctic Peninsula, tracked by magnetic mineral assemblages: Linking ice, ocean, and atmosphere. Geochem. Geophys. Geosystems 17. https://doi.org/10.1002/2016GC006627

Reilly, B.T., Stoner, J.S., Hatfield, R.G., Abbott, M.B., Marchetti, D.W., Larsen, D.J., Finkenbinder, M.S., Hillman, A.L., Kuehn, S.C., Heil, C.W., 2018. Regionally consistent Western North America paleomagnetic directions from 15 to $35 \mathrm{ka}$ : Assessing chronology and uncertainty with paleosecular variation (PSV) stratigraphy. Quat. Sci. Rev. 201, 186-205. https://doi.org/10.1016/j.quascirev.2018.10.016

Reilly, B.T., Stoner, J.S., Wiest, J., 2017. SedCT: MATLAB ${ }^{\mathrm{TM}}$ tools for standardized and quantitative processing of sediment core computed tomography (CT) data collected using a medical CT scanner. Geochem. Geophys. Geosystems 18, 3231-3240. https://doi.org/10.1002/2017GC006884 
1396

1397

1398

1399

1400

1401

1402

1403

1404

1405

1406

1407

1408

1409

1410

1411

1412

1413

1414

1415

1416

1417

1418

1419

1420

1421

1422

1423

1424

1425

1426

1427

1428

1429

1430

1431

1432

1433

1434

1435

1436

1437

1438

1439

1440

1441

Reimer, P.J., Bard, E., Bayliss, A., Beck, J.W., Blackwell, P.G., Ramsey, C.B., Buck, C.E., Cheng, H., Edwards, R.L., Friedrich, M., Grootes, P.M., Guilderson, T.P., Haflidason, H., Hajdas, I., Hatté, C., Heaton, T.J., Hoffmann, D.L., Hogg, A.G., Hughen, K.A., Kaiser, K.F., Kromer, B., Manning, S.W., Niu, M., Reimer, R.W., Richards, D.A., Scott, E.M., Southon, J.R., Staff, R.A., Turney, C.S.M., Plicht, J. van der, 2013. IntCal13 and Marine13 Radiocarbon Age Calibration Curves 0-50,000 Years cal BP. Radiocarbon 55, 1869-1887. https://doi.org/10.2458/azu_js_rc.55.16947

Reusche, M.M., Marcott, S.A., Ceperley, E.G., Barth, A.M., Brook, E.J., Mix, A.C., Caffee, M.W., 2018. Early to Late Holocene Surface Exposure Ages From Two MarineTerminating Outlet Glaciers in Northwest Greenland. Geophys. Res. Lett. 0. https://doi.org/10.1029/2018GL078266

Rignot, E., Kanagaratnam, P., 2006. Changes in the Velocity Structure of the Greenland Ice Sheet. Science 311, 986-990. https://doi.org/10.1126/science.1121381

Rignot, E., Steffen, K., 2008. Channelized bottom melting and stability of floating ice shelves. Geophys. Res. Lett. 35. https://doi.org/10.1029/2007GL031765

Rignot, E., Velicogna, I., van den Broeke, M.R., Monaghan, A., Lenaerts, J.T.M., 2011. Acceleration of the contribution of the Greenland and Antarctic ice sheets to sea level rise. Geophys. Res. Lett. 38, L05503. https://doi.org/10.1029/2011GL046583

Shroyer, E.L., Padman, L., Samelson, R.M., Münchow, A., Stearns, L.A., 2017. Seasonal control of Petermann Gletscher ice-shelf melt by the ocean's response to sea-ice cover in Nares Strait. J. Glaciol. 63, 324-330. https://doi.org/10.1017/jog.2016.140

Simon, Q., Bourlès, D.L., Thouveny, N., Horng, C.-S., Valet, J.-P., Bassinot, F., Choy, S., 2018. Cosmogenic signature of geomagnetic reversals and excursions from the Réunion event to the Matuyama-Brunhes transition (0.7-2.14 Ma interval). Earth Planet. Sci. Lett. 482, 510-524. https://doi.org/10.1016/j.eps1.2017.11.021

Skinner, L.C., McCave, I.N., 2003. Analysis and modelling of gravity- and piston coring based on soil mechanics. Mar. Geol. 199, 181-204. https://doi.org/10.1016/S00253227(03)00127-0

Snowball, I., Mellström, A., Ahlstrand, E., Haltia, E., Nilsson, A., Ning, W., Muscheler, R., Brauer, A., 2013. An estimate of post-depositional remanent magnetization lock-in depth in organic rich varved lake sediments. Glob. Planet. Change, Magnetic iron minerals in sediments and their relation to geologic processes, climate, and the geomagnetic field 110, 264-277. https://doi.org/10.1016/j.gloplacha.2013.10.005

Snowball, I., Zillén, L., Ojala, A., Saarinen, T., Sandgren, P., 2007. FENNOSTACK and FENNORPIS: Varve dated Holocene palaeomagnetic secular variation and relative palaeointensity stacks for Fennoscandia. Earth Planet. Sci. Lett. 255, 106-116. https://doi.org/10.1016/j.eps1.2006.12.009

Stober, J.C., Thompson, R., 1979. An investigation into the source of magnetic minerals in some Finnish lake sediments. Earth Planet. Sci. Lett. 45, 464-474. https://doi.org/10.1016/0012-821X(79)90145-6

Stocker, T.F., Qin, D., Plattner, G.-K., Tignor, M., Allen, S.K., Boschung, J., Nauels, A., Xia, Y., Bex, V., Midgley, P.M., 2013. Climate Change 2013: the Physical Science Basis. Working Group I Contribution to the Fifth Assessment Report of the Intergovernmental Panel on Climate Change 2013. URL Httpswww Google Combooks.

Stoner, J.S., Channell, J.E.T., Mazaud, A., Strano, S.E., Xuan, C., 2013. The influence of highlatitude flux lobes on the Holocene paleomagnetic record of IODP Site U1305 and the 
1442

1443

1444

1445

1446

1447

1448

1449

1450

1451

1452

1453

1454

1455

1456

1457

1458

1459

1460

1461

1462

1463

1464

1465

1466

1467

1468

1469

1470

1471

1472

1473

1474

1475

1476

1477

1478

1479

1480

1481

1482

1483

1484

1485

1486

northern North Atlantic. Geochem. Geophys. Geosystems 14, 4623-4646. https://doi.org/10.1002/ggge.20272

Stoner, J.S., Jennings, A., Kristjánsdóttir, G.B., Dunhill, G., Andrews, J.T., Hardardóttir, J., 2007. A paleomagnetic approach toward refining Holocene radiocarbon-based chronologies: Paleoceanographic records from the north Iceland (MD99-2269) and east Greenland (MD99-2322) margins. Paleoceanography 22. https://doi.org/10.1029/2006PA001285

Stuiver, M., Pearson, G.W., Braziunas, T., 1986. Radiocarbon age calibration of marine samples back to 9000 cal yr BP. Radiocarbon 28, 980-1021.

Suganuma, Y., Yokoyama, Y., Yamazaki, T., Kawamura, K., Horng, C.-S., Matsuzaki, H., 2010. $10 \mathrm{Be}$ evidence for delayed acquisition of remanent magnetization in marine sediments: Implication for a new age for the Matuyama-Brunhes boundary. Earth Planet. Sci. Lett. 296, 443-450. https://doi.org/10.1016/j.epsl.2010.05.031

Syvitski, J.P.M., Andrews, J.T., Dowdeswell, J.A., 1996. Sediment deposition in an icebergdominated glacimarine environment, East Greenland: basin fill implications. Glob. Planet. Change, Impact of Glaciations on Basin Evolution: Data and Models from the Norwegian Margin and Adjacent Areas 12, 251-270. https://doi.org/10.1016/09218181(95)00023-2

Thompson, R., Turner, G.M., 1979. British geomagnetic master curve 10,000-0 yr B.P. for dating european sediments. Geophys. Res. Lett. 6, 249-252.

Tinto, K.J., Bell, R.E., Cochran, J.R., Münchow, A., 2015. Bathymetry in Petermann fjord from Operation IceBridge aerogravity. Earth Planet. Sci. Lett. 422, 58-66. https://doi.org/10.1016/j.epsl.2015.04.009

Valet, J.-P., Bassinot, F., Bouilloux, A., Bourlès, D., Nomade, S., Guillou, V., Lopes, F., Thouveny, N., Dewilde, F., 2014. Geomagnetic, cosmogenic and climatic changes across the last geomagnetic reversal from Equatorial Indian Ocean sediments. Earth Planet. Sci. Lett. 397, 67-79. https://doi.org/10.1016/j.eps1.2014.03.053

Velicogna, I., Sutterley, T.C., Broeke, M.R. van den, 2014. Regional acceleration in ice mass loss from Greenland and Antarctica using GRACE time-variable gravity data. Geophys. Res. Lett. 41, 8130-8137. https://doi.org/10.1002/2014GL061052

Verosub, K.L., 1977. Depositional and postdepositional processes in the magnetization of sediments. Rev. Geophys. 15, 129-143. https://doi.org/10.1029/RG015i002p00129

Walczak, M.H., Mix, A.C., Willse, T., Slagle, A., Stoner, J.S., Jaeger, J., Gulick, S., LeVay, L., Kioka, A., The IODP Expedition 341 Scientific Party, 2015. Correction of non-intrusive drill core physical properties data for variability in recovered sediment volume. Geophys. J. Int. 202, 1317-1323. https://doi.org/10.1093/gji/ggv204

Walczak, M.H., Stoner, J.S., Mix, A.C., Jaeger, J., Rosen, G.P., Channell, J.E.T., Heslop, D., Xuan, C., 2017. A 17,000 yr paleomagnetic secular variation record from the southeast Alaskan margin: Regional and global correlations. Earth Planet. Sci. Lett. 473, 177-189. https://doi.org/10.1016/j.epsl.2017.05.022

Washam, P., Münchow, A., Nicholls, K.W., 2018. A decade of ocean changes impacting the ice shelf of Petermann Gletscher, Greenland. J. Phys. Oceanogr. https://doi.org/10.1175/JPOD-17-0181.1

Washam, P., Nicholls, K.W., Münchow, A., Padman, L., in review. Stronger summer surface melt thins Greenland ice shelf by enhancing basal melt. J. Glaciol. 
Weeks, R., Laj, C., Endignoux, L., Fuller, M., Roberts, A., Manganne, R., Blanchard, E., Goree, W., 1993. Improvements in long-core measurement techniques: applications in palaeomagnetism and palaeoceanography. Geophys. J. Int. 114, 651-662. https://doi.org/10.1111/j.1365-246X.1993.tb06994.x

Wheatcroft, R.A., Goñi, M.A., Richardson, K.N., Borgeld, J.C., 2013. Natural and human impacts on centennial sediment accumulation patterns on the Umpqua River margin, Oregon. Mar. Geol. 339, 44-56. https://doi.org/10.1016/j.margeo.2013.04.015

Xuan, C., Channell, J.E.T., 2009. UPmag: MATLAB software for viewing and processing u channel or other pass-through paleomagnetic data. Geochem. Geophys. Geosystems 10. https://doi.org/10.1029/2009GC002584

Yoshimori, M., Suzuki, M., 2018. The relevance of mid-Holocene Arctic warming to the future. Clim. Past Discuss. 1-28. https://doi.org/10.5194/cp-2018-175

Zreda, M., England, J., Phillips, F., Elmore, D., Sharma, P., 1999. Unblocking of the Nares Strait by Greenland and Ellesmere ice-sheet retreat 10,000 years ago. Nature 398, 139-142. 